\title{
La fotografía. entre el dibujo y la virtualidad
}

Göran SONESSON

Universidade de Lund/Suécia 


\section{Resumen}

La tarea de la semiótica de la imagen no consiste solamente en determinar la especificidad de la imagen como signo, sino también en describir las particularidades de diferentes imágenes, como son, por ejemplo, el dibujo, la fotografía y la imagen de computadora. El presente texto describe, primero, el desarrollo del signo del tipo de la imagen en la historia de la humanidad y considera, después, las particularidades de esos signos en cuanto a su posible reproducción y su límite con la realidad. La cuarta parte del ensayo estudia la fotografía en su capacidad de signo indexical e icónico, e insiste sobre el carácter global de las reglas de reproducción que opone ese tipo de imagen al dibujo. En la última parte, estudiamos el cambio en la definición de la fotografía que ha resultado de la emergencia de la imagen sintética y de la realidad virtual.

\section{Palavras-chave}

fotografía, signo, índices, icóno, imagen virtual, multimedia, televisión

\section{Abstract}

The task of pictorial semiotics is not only to determine the specificity of the picture as a sign, but also to describe the peculiar nature of different kinds of pictures, such as the drawing, the photograph, and the computer image. The present text first describes the development of the pictorial signs throughout the history of humanity, and then considers the properties which characterise these signs as far as their possibility of repetition and the limits to reality are concerned. The fourth part of the essay studies indexical and iconic sign character of photography and emphasise the global character of its rules of reproduction as opposed to those of hand-made pictures. In the last part, we investigate the ways in which the definition of photography has changed as a consequence of the emergence of synthetic pictures as well as virtual reality.

\section{Key words}

sign, index, icon, virtual image, multimedia, television 


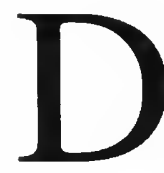

esde dos puntos de vista, la fotografía representa un momento de ruptura dentro de la historia de la imagen: perfecciona la reproductibilidad del signo y, por lo tanto, la división entre el tipo y sus ejemplares; y da un paso decisivo hacía el mundo virtual con su obliteración de la distinción entre expresión y contenido.

La imagen es un signo, por lo que, una vez creada, se puede repetir infinitamente. Sin embargo, no ha sido así durante la historia de la humanidad, en oposición a lo que ha pasado desde tiempos inmemoriales en el caso del signo competidor, la palabra. Desde la prehistoria hasta hace poco ha predominado la imagen única, aunque ya durante el renacimiento se empezaron a inventar procedimientos que permitirían su reproducción, de la xilografía hasta la actual impresora láser. Gracias a la computadora, la imagen por fin puede realizar otra característica del signo prototípico, puede constar de elementos repetibles y acabados, como la lengua, aunque en la forma particular de las imágenes

Cuando la imagen pasa de la simple reproducción mecánica a la producción digital, como en el caso de la imagen virtual, tiende, por otro lado, a perder su calidad de signo, o así lo parecería. Quizás la imagen televisiva podría estar ya a punto de confundirse con la realidad misma.

La imagen es primero superficie. Y como superficie se vuelve signo. Nuestra tarea es estudiar en qué sentido es signo antes de reproducirse sin límites y antes de presentarse como el resultado de combinaciones infinitas de elementos mínimos. Pero también es necesario entender de qué propiedades del signo surge la posibilidad de la reproducción y, más tarde, la producción a partir de elementos 
mínimos - y por qué, al mismo tiempo, su calidad de signo parece hoy precaria.

\section{Historia y ideología de la imagen}

De la época prehistórica hasta el renacimiento predomina la imagen única. No hay que ver un valor en la unicidad, como se hizo más tarde con la creación del concepto de arte. Para empezar, la imagen única es una limitación: un tipo de signo con una sola réplica (copia). Durante mucho tiempo sólo le fue posible a una minoría poseer una imagen, poder verla y eventualmente permitir a otros copiarla. En algunos países y climas, el fresco fue reemplazado rápidamente por pinturas sobre madera, cobre o tela, que se transportan con más facilidad. Apareció un mercado abierto para la venta de imágenes y el libro y otros impresos difundieron ampliamente las imágenes. Los procedimientos para reproducir imágenes desarrollados posteriormente (xilografía, grabado en cobre, etc.) hicieron posible realizar cada vez mayor cantidad de copias conservando el parecido con el original. La fotografía perfeccionó lo que Ivins (1953:4, 113ff) llamó "el enunciado repetible con exactitud mediante imágenes", es decir, la producción de incontables réplicas de cada imagen original. Nuevas formas visuales omnipresentes que se reproducen de inmediato nacieron con el cine y la televisión, más recientemente con los multimedios y otras expresiones visuales relacionadas con la computadora.

\section{La historia como proceso de densificación de imágenes}

Es posible ver la historia del mundo occidental como una "densificación" progresiva del número existente de imágenes, o sea, como un aumento del número de imágenes por habitante (Ramírez, 1981). Pero ver el desarrollo en términos puramente cuantitativos es poco informativo; son los distintos procesos que están tras esta inflación que son significativos. 
Al menos desde que se inventó la fotografía, los tipos de imágenes han aumentado. En general, hay dos formas de crear una imagen: a mano, es decir, normalmente con algún instrumento sencillo que se sostiene con una mano, como por ejemplo, un lápiz, un pincel o un tiralíneas, o con ayuda de algún aparato mecánico más complejo. El primero se puede llamar un método quirográfico y el segundo, un método tecnográfico (Véase Gubern, 1987b) o mecanográfico (Sonesson, 1992). Ejemplos de imágenes realizadas tecnográficamente son las fotografías, los videofilmes y la gráfica computarizada. En general toma mucho menos tiempo realizar una imagen tecnográfica que una quirográfica de tamaño y complejidad equivalente. El modo tecnográfico de producir imágenes es además accesible a un número de personas mucho mayor, ya que no requiere ninguna destreza que exija un aprendizaje largo o talento innato. El criterio es entonces no producir imágenes artísticas, sino un elemental traslado de información del objeto representado.

La historia occidental de la imagen también ha tenido como consecuencia un creciente número de réplicas (o ejemplares), a la vez en números absolutos y en relación a cada tipo de imagen. Naturalmente, siempre ha sido posible producir copias y desde que la pintura se transformó en un tipo de artesanía, esa manera de proceder ha sido de importancia fundamental, tanto como procedimiento de aprendizaje y como ejercicio de la profesión, donde los libros modelo durante mucho tiempo han jugado un papel central. Los procedimientos de reproducción mecánicos hacen posible producir cada vez más copias que mantienen el parecido con la plancha original (equivalente al original o que en cualquier caso está más cercana a éste). Debido a ese desarrollo la imagen ha llegado a ser un signo cada vez más parecido al lingüístico, como lo destaca Ivins (1953), de tal modo que ahora cada enunciado puede repetirse exactamente igual; en otras palabras, también en el caso de imágenes varias réplicas pueden producirse a partir de un solo tipo. Es en esta fase que la obra de arte, según dice Benjamin (1974), llega a ser algo mecánicamente reproducible, o sea, en el arte como fuera de él, un tipo de signo que puede generar muchas 
réplicas. Por lo tanto, pierde su "aura", que ha venido a asociarse con el carácter de unicidad al que se le da un alto valor.

Sin embargo, el número de imágenes a niveles más abstractos también ha aumentado, a saber, el número de clases de imágenes. Esa observación vale en términos de principios de construcción: al grabado en piedra y al dibujo le han seguido la xilografía y la pintura al óleo; más tarde la fotografía, el vídeo musical, la imagen computarizada, el multimedium, etc. Esto también es válido en términos de uso. Con el amplio acceso a la educación y la aparición de distintos medios de comunicación, la propaganda y la industria del entretenimiento, las imágenes han adquirido un uso social en vez de tener un uso únicamente individual, y sus funciones son más especializadas, lo mismo que sus consecuentes rasgos particulares. Al mismo tiempo han surgido más canales a través de los cuales las imágenes pueden circular en la sociedad. Durante mucho tiempo, la mayor parte de imágenes se encontraban en iglesias y palacios, a los cuales la mayoría de las personas no tenían acceso en cualquier momento ni las veces que lo desearan. Desde el siglo antepasado aparecen imágenes en carteles publicitarios en las calles, en diarios, revistas, en museos públicos, galerías de arte, etc. Además, la televisión las difunde en el hogar, y gracias a las computadoras y al Internet, también pueden fabricarse en casa para una difusión posterior al mundo. Este desarrollo, al menos en parte, es el resultado del creciente número de tipos de imágenes, copias y clases de imágenes.

Finalmente tenemos un número mayor de actos de comunicación visual claramente limitados. Los inscripciones en piedras, los frescos y las pinturas en iglesias y museos se encuentran en principio para siempre en un lugar, donde cualquiera, en cualquier momento, los puede encontrar. La tarjeta postal, la imagen de propaganda y la imagen televisiva son, por el contrario y en grado progresivo, activamente dirigidas por un emisor a receptores relativamente pasivos durante períodos limitados. El encuentro entre la imagen y su receptor sólo puede ocurrir en lugares y tiempos determinados: aún la copia se disuelve en varios acontecimientos en el tiempo (aunque relativamente pocos). Esto es válido también en el Internet, donde es el receptor quien introduce el tiempo para el acto de comunicación 
conectándose al archivo de imágenes, al archivo de programas, o a la página web (Véase Sonesson, 1995b).

En la transición de la reproducción mecánica a la digital se aceleran y amplían todos estos procesos. La aureola del arte, ya en decadencia, cae estrepitosamente al suelo.

\section{$1.2 \mathrm{El}$ acto gráfico elemental y la ideología de los pixeles}

Percibimos la imagen como algo indivisible, algo ininterrumpido, a diferencia de la lengua, que se presenta como compuesta de un número finito de pequeñas partes. En una terminología más popular que exacta se dice a menudo que el idioma es digital y la imagen análoga.

El niño descubre el acto gráfico elemental (véase Gibson, 1978; 1980; Lurçat, 1974) cuando su interés cambia del movimiento manual, como tal, a las huellas que estos movimientos dejan en el papel, o en otro soporte, cuando la mano sostiene un lápiz y el lápiz se apoya contra el papel. Más adelante, el acto gráfico se divide en dos líneas de desarrollo completamente diferentes: una parte de su adquisición se adiestra por la representación de una cantidad limitada de líneas y curvas que llamamos letras; la otra parte disfruta de una libertad relativa, al menos hasta que llegue al estadio del realismo, tan difamado por los pedagogos. De acuerdo a una de las metáforas más antiguas del mundo de la computación, se dice que la escritura (y también - aunque esto sea menos evidente para el lego la lengua hablada) es digital mientras que la imagen es análoga. Esto no quiere decir que por regla la imagen sea icónica, es decir, igual a lo que representa, sino que es continua, tal como la realidad - tal como lo es una esfera tradicional de reloj, a diferencia del indicador de cifras del reloj de cuarzo.

La semiótica de baratijas de la década de los sesenta quería hacernos creer que todos los sistemas de significación funcionaban de la misma forma que el lenguaje verbal. El idioma, según han demostrado los lingüistas, está compuesto de pequeñas partes, las 
palabras, que tienen expresión y contenido y que pueden seguir dividiéndose en partes aún más pequeñas, que sólo existen en el nivel de expresión (fonema, grafema), y eventualmente también en pequeñas partes independientes de la expresión en el nivel del contenido (semas, etc.). Además, el signo lingüístico es considerado arbitrario en dos sentidos: la expresión, por ejemplo el sonido, no se parece al contenido, lo cual se muestra en las diferencias entre idioma e idioma; y el signo como totalidad no está determinado por el mundo de la percepción, lo cual se deduce del hecho de que distintos idiomas establecen límites entre ciertos fenómenos en distintos lugares. Es por eso que muchos semióticos opinaban, en esa época, que la imagen también debería ser divisible en partes pequeñas y arbitrarias. Esto afirmaban René Lindekens, Jean-Marie Floch, Felix Thürlemann, Groupe $\mu$ y Umberto Eco, por nombrar los más prominentes.

Umberto Eco, pese a ser indudablemente el propagandista más exitoso de esta teoría, modificó posteriormente su concepción. Aunque siguió sosteniendo radicalmente su afirmación sobre la convencionalidad de la imagen, negó a la vez la posibilidad de analizar la imagen en pequeñas partes; por lo tanto, se adhirió a la sabiduría tradicional. Con anterioridad y con más precisión el filosofo norteamericano, Nelson Goodman, había expresado la misma opinión; también para él la imagen era convencional como el idioma, pero se diferenciaba por ser "compacta" Esto implica que a pesar de lo extenso que haya podido ser el análisis de la imagen, siempre era posible continuar la división. Es decir, se podía introducir una tercera unidad entre cada par de las unidades anteriormente establecidas y otra nueva unidad entre cada uno de los pares resultantes, y así, sucesivamente, al infinito. Naturalmente, esto equivale a decir que la imagen no tiene unidades, puesto que cada división tiene el mismo valor (véase Sonesson, 1989a; 1995a).

Ahora muchas cosas (entre otras los resultados de la psicología de la percepción) parecen indicar que es lo contrario lo que es cierto. Mientras Eco y Goodman afirman que la imagen se parece al idioma por ser convencional, pero se diferencia de éste por no ser divisible en unidades menores, existe en realidad toda la razón 
(como nos enseña la psicología de la percepción) de suponer que la imagen está basada fundamentalmente en relaciones de igualdad (es icónica), y que se analiza en rasgos (véase Sonesson, 1989a; 1992a; 1998a, 2000). De esta manera, la imagen es, a su modo, también digital.

Se podría pensar que el carácter digital de la imagen se confirma por la posibilidad de crear imágenes en computadora, sobre todo por la existencia de imágenes compuestas de pixeles o "puntos pintados" - frente a las gráficas, que resultan por vectores. La pantalla, en el primer caso, y tal vez el papel impreso, está cubierta de una red de puntos blancos y negros (suponiendo que no haya acceso al color); la imagen resultante consta de una serie de rasgos que pueden parafrasearse como "blanco en posición 1,1" "negro en posición 1,2", etc. En el segundo, sólo se indican las coordenadas del inicio y término de una figura. La figura es un todo continuo, no una reunión de puntos. Razonar así, no obstante, es mezclar los niveles de análisis: es confundir forma y sustancia.

También los sonidos del idioma tienen características innumerables y se pueden dividir de distintas maneras de acuerdo con éstas; aunque, mientras algunas características del sonido son irrelevantes en todos los idiomas, otras se usan en ciertos idiomas y en otros no. Como forma se cuenta sólo los rasgos de la expresión que conducen a la percepción del contenido y viceversa; los demás pertenecen a la substancia. En sueco, los rasgos que diferencian la "r" de la "l" son parte de la forma; la diferencia entre r-gutural y la ralveolar pertenece a la substancia del idioma sueco, pero no a la del castellano (en algunas variantes). Un análisis de rasgos que tome en cuenta las características del sonido que diferencian la " $r$ " de la " $l$ " es irrelevante para el idioma japonés; de la misma manera que no tiene tampoco importancia para el idioma sueco la diferencia entre la r-gutural y la r-alveolar.

Eco (1968:215ff; 1976:323f) cae exactamente en este tipo de paralogismo cuando afirma que la fotografía rastreada en un diario y la técnica de enviar una imagen de un lugar a otro por medio de la red telefónica, demuestran que es posible dividir la imagen en rasgos. No obstante, esto es completamente irrelevante, ya que no es 
este análisis el que nos permite ver la imagen como signo de algo. Se puede decir tanto de la imagen rastreada como la de la telefoto y la de la informática, que materialmente son una acumulación de puntos, comparable a la imagen de un rompecabezas que se ensambla con distintas piezas; sin embargo, de manera similar al caso del rompecabezas, la imagen, como tal, está enteramente compuesta de otras unidades, que pueden funcionar en la percepción, una vez que la imagen materialmente se una nuevamente, después de que el rompecabezas haya sido armado, o las señales digitales hayan llegado a su destino.

Al igual que otros signos, la imagen existe sólo cuando es percibida por alguien. Evidentemente, las irregularidades de los contornos también pertenecen a lo que se percibe - más o menos dependiendo de la calidad de impresión. No obstante es algo que se nota al lado de lo que la imagen representa - como cuando se escucha a un extranjero hablar un español correcto sin dejar por eso de notar su acento. Al igual que el habla del extranjero manifiesta el idioma del hablante nativo, al mismo tiempo que connota lo extranjero, tal vez hasta lo francés, lo americano, lo chileno, etc.; de la misma manera manifiesta la imagen informática la imagen y connota la impresión de la computadora. Sin embargo, esto pronto tal vez sea verdad sólo en el caso de la imagen informática añeja.

En la percepción, la imagen se deja analizar en rasgos, como lo prueba la existencia de imágenes muy abstractas o simplemente esbozadas (véase Sonesson, 1989a; 1992a; 1998a; 2000). Actualmente, gracias a la computadora, se logra también la creación de imágenes a partir de combinaciones de rasgos. Los elementos forman una retórica debido a que están más extendidos que en la lengua.

\subsection{Las imágenes de la mano y de la máquina}

Percibir superficies es importante para la posibilidad de supervivencia de todos los animales; es solamente determinando las relaciones mutuas de las superficies que estos se pueden orientar en el mundo de la experiencia. No obstante, sólo el hombre ve las marcas adicionadas a la superficie, según lo afirma el psicólogo 
norteamericano James Gibson (1980). Estas marcas pueden ser de distintos tipos, por ejemplo, manchas de color, líneas o sombras proyectadas; y pueden producirse de distintas maneras: con los dedos, con un lápiz, con un pincel, con algún instrumento para grabar, un compás, o con un instrumento algo más complicado como la prensa, el aparato fotográfico o el proyector. Las marcas sobre la superficie pueden estar desordenadas y, por lo tanto, ser manchas de suciedad. Si son simétricas o regulares de modo alguno, conforman un tipo de ornamento; pero si las marcas tienen una forma que puede interpretarse con referencia a una escena perceptiva probable, estamos entonces frente a una imagen.

Contrariamente a lo que pasa en la historia del arte, la imagen se entiende aquí como algo cuyo plano de expresión es, materialmente, una superficie (relativamente) plana. Tanto para la semiótica como para la psicología, la posibilidad de signos icónicos tridimensionales (esculturas, maniquíes, espantapájaros, etc.) no presenta en absoluto el mismo problema que la producción de una escena perceptiva sobre una superficie. Es evidente que, de acuerdo de Gibson, muchas de las imágenes más famosas del último siglo se podrían clasificar como ornamentos o hasta como manchas. El triángulo blanco sobre fondo blanco de Malevitj parecería un simple ornamento; las telas azules de Yves Klein no llegarían a ornamento, serían simplemente tablas pintadas y las obras de Pollock serían manchas de suciedad. Lo que en realidad diferencia estas pinturas del ornamento y la suciedad es que en nuestro mundo artístico contemporáneo, al mismo tiempo que éstas son marcas regulares o caóticamente diseminadas sobre una superficie, se pueden interpretar como teniendo lo que Gibson llama un "significado referencial" - pese a que este significado en general no puede ser identificado como una escena perceptiva corriente (véase Sonesson, 1989a, III.3.2.; 1996b, 1999a; 2001).

Según Gibson (1978:229) hay dos tipos de imágenes: la quirográfica, es decir la imagen hecha manualmente y la fotográfica. Los ejemplos dados anteriormente parecen mostrar una mayor variación y una diferencia menos clara: las imágenes hechas literalmente a mano son sólo aquellas pintadas con los dedos; también la 
cámara debe sostenerse con una o dos manos. En realidad es fácil entender la base de la división de Gibson; aún cuando la acción de la mano se medie con un lápiz, un compás o un instrumento para grabar, es la mano la que crea las marcas línea por línea y punto por punto, mientras que la intervención de la mano en la cámara es global, al sostener la cámara y apretar el obturador en un momento determinado. Cada curva de la línea dibujada y también cada momento de su continuación depende de la microdecisión que gobierna la mano. Pero una vez que la cámara está enfocada y el obturador apretado, entonces el "pincel natural", como Fox Talbot llamaba al proceso de fotografiar, dibuja toda la figura de una vez. Se puede decir entonces que la mano es el personaje principal, en el momento en que la cámara deja de serlo (véase Sonesson, 1999a; 2001).

Una división binaria de ese tipo sólo puede ser posible si el término fotográfico se toma en un sentido amplio, porque la imagen fílmica puede ser, en el fondo, lo mismo que la fotografía, pero la imagen de vídeo es algo completamente diferente. Por esto se puede introducir, siguiendo a Roman Gubern (1987b:46f), el término tecnográfico como el verdadero opuesto del quirográfico y a lo anterior agregar la imagen fotográfica, cinematográfica y videográfica. Sin embargo, habría que incluir aquí también lo que el mismo Gubern (1987a:73ss) en otro libro ha llamado "la imagen sintética" es decir, imágenes producidas con la ayuda de la computadora (véase Sonesson, 1989b, III.1.2.; 1996b, 1999a; 2001). Nosotros, al clasificar la imagen informática como tecnográfica, encontramos una contradicción extraña: aunque el carácter técnico de la imagen informática es mucho más avanzado que el de la cámara, éste no nos obliga a tomar decisiones globales. El acto de dibujar se dirige en gran medida por la mano, mediado por el ratón, que por cierto no es un medio expresivo tan flexible como el lápiz o el instrumento de grabado (aunque un efecto semejante posiblemente se puede obtener por medio de un tablero de dibujo digital). Pese a su carácter altamente tecnográfico, pareciera que la gráfica computarizada recupera algunas ventajas quirográficas. 


\section{La imagen como tipo y réplica}

En un texto clásico, Walter Benjamin proclamó, ya en la década de los 30, el inicio de la era de la reproducción mecánica de la obra de arte. Por un lado, esta afirmación era prematura; en lugar de perder su aura, que alguna vez fue liviana como un soplo, el arte la ha vuelto a fundir en bronce; el mundo del arte, más que nunca, se basta a sí mismo. Por otro lado, la predicción de Benjamin no era suficientemente radical. La repetición mecánica se ha convertido en digital, lo cual implica que su tipicalidad ya no parte de un original previo, que es percibido como tal. Y de haber sido un medio sólo para la reproducción, ha llegado finalmente a ser también la forma misma de la producción de la imagen (véase Sonesson, 1997a, b; 1999, 2001).

\subsection{Más allá de la reproducción mecánica en la retórica}

Benjamin habla de cómo la imagen, cuando ya ha sido creada, puede copiarse y difundirse en nuevos ejemplares. Si la página web sirve nada más para reproducir una pintura al óleo escaneada sigue siendo un medio de reproducción; pero si uno combina partes de imágenes anteriores en un programa gráfico para obtener una nueva imagen, la computadora se vuelve en un medio de producción. La mecanización de las formas de construcción no coinciden necesariamente con las formas de distribución, aún cuando determinadas formas de construcción, como el cine y la computadora, de antemano parecen estar condicionadas a una distribución mecánica.

Para verlo, hay que partir de una retórica social. Los formalistas rusos sostenían que la particularidad del arte consistía en hacer ajeno, desautomatizar nuestras costumbres de percepción. El lenguaje cotidiano (y en analogía con éste las imágenes cotidianas) es tan habitual para nosotros que vemos directamente a través de la expresión hacía el significado; nuevas corrientes artísticas rompen con este hábito, pero pronto se vuelven tan habituales que una nueva corriente tiene que introducir una nueva ruptura contra esta habituación. 
No fue sin razón que los formalistas se llamaron a sí mismos formalistas - y fueron más tarde acusados por los marxistas exactamente por esta característica. Existe a pesar de todo una teoría implícita de la mente, la sociedad y la historia en el concepto de "hacer ajeno": nuestra percepción se vuelve una costumbre con el tiempo, de manera tal que no notamos lo que vemos; la sociedad establece sus medios de comunicación habituales y sanciona ciertas corrientes artísticas que así se vuelven totalmente transparentes para el significado; la historia es una serie de rupturas de la norma que se absorben en la norma para ser expuestas a nuevas rupturas de la norma.

La escuela de Praga hizo el carácter histórico y social de la norma explícito. La norma en vigor consiste en obras ejemplares y preceptos para crear obras; interpretar obras con la ayuda de otras obras ejemplares y otro canon basta para producir una desautomatización. Esto significa que finalmente podemos en serio decir de la imagen artística lo que han dicho los formalistas rusos y la escuela de Praga, con la obra literaria en mente: que surgen como actos divergentes no sólo en relación a modos anteriores de hacer arte, sino también en relación a los medios estándares, el idioma respectivamente la imagen cotidiana.

La división del signo visual fundada en la terminología coloquial da origen a tres categorías visuales (Sonesson, 1987; 1992a; 1997a, b): las clases de construcción, definidas por lo que es relevante en la expresión en relación a lo que es relevante en el contenido, lo cual, por ejemplo, diferencia la fotografía de la pintura; las clases de función, que se dividen de acuerdo a efectos sociales anticipados, por ejemplo, que la publicidad tenga por meta vender productos, que la sátira ridiculice a algo; y las clases de circulación, caracterizadas por los canales por los que las imágenes circulan en la sociedad, lo cual hace del cartel algo diferente de la imagen del diario o de la tarjeta postal algo distinto del póster.

Aquí está dada la primera fuente para una retórica visual: mediante la mezcla de distintas clases de construcción, clases de función y clases de circulación, se produce una ruptura de nuestras expectativas (Sonesson, 1996a, b; 1997b). Entre la mezcla de clases 
de construcción se puede contar el collage cubista, cuyos materiales son heterogéneos. Podemos encontrar una mezcla de clases de función en la conocida propaganda de Benetton, en la que una imagen noticiosa se ha unido a una imagen de publicidad. Una fuente más abundante de ruptura de la norma es, sin embargo, las expectativas que tenemos de encontrar ciertas correlaciones entre clases de construcción, clases de función y clases de circulación. Gran parte del modernismo (incluso del postmodernismo) ha consistido en romper, de forma siempre nueva, con el prototipo de la obra de arte que reinó en el siglo XIX: una pintura al óleo (clase de construcción) con función estética (clase de función) que circula por galerías privadas y estatales, museos y salones (clase de circulación). En este sentido, el modernismo no ha sido otra cosa que un gigantesco proyecto retórico.

No obstante, también la misma historia de los medios de comunicación y de los sistemas de signos sirve para deshacer las conexiones esperadas. Esto es válido también en un plano más general: ya con el advenimiento de la xilografía el signo visual no depende para su distribución de las creación artesanal de copias; pero solamente la imagen computarizada logra romper completamente con la parte manual de la construcción.

\subsection{La retórica del referente y de sus partes}

Las posibilidad retóricas de la imagen se hacen más grandes y la simple reproducción se vuelve producción, cuando la imagen se puede componer de diferentes partes, divididas de manera pertinente y no en forma de piezas de rompecabezas. Lejos de depender de la realidad, la imagen puede entonces tomar la forma de un enunciado que expresa opiniones sobre el mundo.

En un intento por definir lo específico en las imágenes fotográficas, varios semióticos concluyeron hace poco que éstas son más indexicales (basadas en la proximidad) que icónicas; parten del supuesto que en algún momento anterior la cámara y la película sensible se encontraba en cercanía real al motivo (ver Vanlier, 1983, Dubois 1983, Schaeffer 1987 y la crítica en Sonesson 1989b y más 
adelante). Mediante la luz que envía el objeto fotografiado se produce una huella en la emulsión fotográfica, no tan diferente a la huella del pie en la arena. Como prueba se necesita sólo citar casos extremos como el rayograma, el schadograma y otros fotogramas.

Aún cuando la huella dejada por la luz en fotografías más clásicas es más mediada existe sin duda, como condición para la génesis de la fotografía. Muchas pinturas, tanto aquellas de la infancia de la fotografía (con frecuencia pintadas con una fotografía como modelo), como las obras hiperrealistas de tiempos más recientes, producen la ilusión de exactitud fotográfica, pero al observándolos más en detalle se revelan muy pronto como pinturas. Estas pinturas connotan lo fotográfico, pero esta connotación ilusoria esta cubierta por otra, que connota la pintura de forma mucho más verdadera, algo así como la imitación de un mexicano por un español connota lo mexicano pero más allá de esto aparece una connotación más verdadera del dialecto español.

No se puede decir lo mismo de las imágenes sintéticas. Por más falsa que sea la connotación de lo fotográfico (y desde luego de correspondencia a la realidad), es sin embargo menos turbia. Nada, sino probablemente el carácter extraño del objeto, parece separar estas imágenes de la fotografía verdadera. No obstante es posible, como señala Moles (1971:54; 1981:29), construir el objeto a partir de su imagen y posteriormente hacer la imagen de acuerdo a la verdad.

Al igual que en la cuestión de la iconicidad, es la experiencia - esta vez de proximidad - la que es fundamental, mientras que la cercanía verdadera, exactamente como la igualdad verdadera, se deja poner en duda. La proximidad es una parte del mensaje y sólo en segundo lugar, probablemente también uno de sus supuestos. En la práctica socialmente heredada de lo fotográfico, la fotografía es un testigo de la verdad y esta función se traslada a la imagen sintética, cuyo plano de expresión no se deja distinguir de la fotografía. Y así puede seguir siendo hasta que un día la imagen sintética llegue a ser tan común como la fotografía; entonces estaremos obligados a abandonar esta presuposición cada vez más alejada de la verdad de la existencia de una relación anterior de cercanía entre el motivo 
y la imagen. O si no, debemos descubrir cualidades más sutiles que nos ayuden a separar las dos categorías de imagen.

De acuerdo a Ronald Barthes $(1961 ; 1964)$ la fotografía, a diferencia del dibujo, era un mensaje sin código, que en forma directa apuntaba a la realidad; sólo era posible manipularla a posteriori con ayuda de diversos trucos, después de que el instante de la creación indexical haya pasado. Para la imagen sintética, que se ve igual, no existe sin embargo esta diferencia entre el instante original y el proceso posterior; la realidad surge sólo como último paso de la manipulación.

Existe ahora la posibilidad de partir de una fotografía o hasta de una pintura. En vez de hacer simplemente fotocopias de ellas, se pueden utilizar una computadora y entonces en el proceso de copiar se pueden modificar los matices de los colores y la extensión de los planos de distintos colores, eliminar objetos indeseados y eventualmente dibujar nuevos. No hace falta ningún recorte o pegado como en la antigua técnica del collage; no se necesita como Max Ernst volver a fotografiar el recorte para borrar las junturas. La manipulación puede ser completamente imperceptible. Cuando algunos creadores de publicidad al igual que algunos artistas contemporáneos como Casmo Info usan estas técnicas, no hay, sin embargo, riesgo de su imperceptibilidad; parten de imágenes reconocidas como arte desde hace tiempo y imágenes de publicidad dominantes en el momento actual. Cuando el reconocimiento es previsto, la manipulación misma se transforma en el tema.

Así se vuelve ruptura de norma, "hacer ajeno" - es decir, retórica de la imagen.

\subsection{Dos tipos de tipicalidad}

Un pensamiento fundamental de la semiótica cultural de la escuela de Tartú es que la acumulación tanto de la información como de la mercancía son previas al intercambio y es una característica más elemental y más fundamental de la cultura. De acuerdo a Lotman, el objeto material y la información se parecen, al tiempo que se diferencian de otros fenómenos en dos sentidos: se pueden acumular, mientras que por ejemplo, no se puede acumular el sueño o la 
respiración, y no se incorpora completamente con el organismo, como el alimento, sino permanecen como objetos separados aún después de la recepción. Aquí Lotman parece tratar el signo como pura información, tal vez porque él piensa sobre todo en textos verbales, donde la base material concreta es en alto grado cambiable. Sin embargo, una imagen es tanto objeto material como información, tanto artefacto como objeto de percepción. Por lo tanto podemos acumular imágenes en un doble sentido: como cosa material, en el casillero de un banco, o como experiencia en la mente. En ambos sentidos mantienen una determinada distancia con respecto al cuerpo.

Una parte de las características que Lotman atribuye a la información trae a la memoria las que cita Masuda (1980), uno de los primeros propagandistas de la sociedad de información: la información no es consumible, independiente de cuanto se use, pero se puede trasladar a un nuevo lugar sin que desaparezca de su lugar de partida; no se acumula si no se utiliza como es el caso de bienes materiales sino por un aumento de la utilización y la integración con otra información. Contra Masuda tanto como contra Lotman se puede objetar que la información debe encarnarse en algún tipo de substancia material; prescindiendo completamente de que el acceso a la información dependa de unos aparatos altamente materiales llamados computadoras, discos duros y tocadiscos compactos. En el mundo de las ideas existe interminablemente el contenido de un libro; pero en la realidad, éste muere con el último ejemplar en papel que se pudre o la última persona que muere u olvida el contenido. También la información computarizada es dependiente del desgaste de las unidades de almacenamiento como los discos compactos y los discos duros.

En este sentido todos los bienes de información están temporalmente limitados - aún cuando algunos límites puedan ser relativamente de larga duración. Ronald Posner (1989) distingue dos tipos de artefactos: los transitorios (como el sonido producido por los tacones de una mujer contra el pavimento) y los perdurables (como las huellas que sus zapatos podrían dejar en la arcilla, especialmente si ésta posteriormente se seca). Los artefactos transitorios, en este sentido, también tienen un aspecto material, tal 
como los perdurables; y sólo tienen la particularidad de que se desarrollan en el tiempo, lo cual hace que no se dejen acumular sin ser convertidos. Si dejamos de lado las secuencias animadas, entonces la imagen de computadora debe considerarse como un artefacto perdurable; a pesar de que sea muy fácil ir de una variante a la otra. $\mathrm{Al}$ mismo tiempo, la imagen computarizada no tiene la tangibilidad que esperamos de un artefacto perdurable.

Normalmente, son los artefactos transitorios de Posner cuyo desarrollo en el tiempo hace que de alguna manera parezcan "menos" materiales (porque ese tipo de disparates se tiene que tomar en serio en el estudio del "mundo de la vida"). Es fácil comprender que los pensadores del Siglo de las Luces como Diderot y Lessing pudieron entender el idioma (que deben haber imaginado más que nada en forma de habla) como un "material más sutil" que la imagen, que existe en el tiempo (de cualquier modo hasta que se deje entrar aire a las cavernas prehistóricas o se permita al escape de los automóviles devastar los frescos más tardíos). Pero pese a que normalmente no es un artefacto de tiempo, la imagen informática parece ser "sutil" Harold Innes (1950) diferenciaba todas las culturas de acuerdo a si hacían hincapié en medios almacenables más perdurables pero difíciles de transportar como los tabletas de piedra, o en medios menos perdurables, pero más fáciles de transportar como el papiro - en otras palabras, de acuerdo a la importancia relativa del aspecto acumulativo o de traslado. De modo parecido Metz (1990) ha afirmado que la fotografía, pero no el filme pudieron ser objeto de fetichismo, en el sentido freudiano, precisamente porque el anterior tiene carácter más material (Véase también Sonesson, 1995a). En este sentido la imagen informática está completamente exenta del riesgo del fetichismo; favorece los aspectos de acumulación y traspaso.

La diferencia entre tipo y ejemplar la describe Peirce con los términos "type" y "token" (o "réplica"). En la frase anterior aparece por ejemplo la palabra "y" una vez, considerada como tipo, pero dos veces considerada como ejemplar. La letra "l" es también un sólo tipo, al mismo tiempo que en la primera oración del párrafo aparecen cinco ejemplares. Parece natural ampliar este razonamiento 
a otros sistemas de significados; una reproducción de la Mona Lisa es del mismo tipo que otra reproducción, pero ambas constituyen dos ejemplares de los muchos que existen. También considerado como una totalidad este artículo es un solo tipo, pero aparecerá en tantos ejemplares como se imprima esta revista.

No es evidente que la relación entre tipo y ejemplar siempre sea de la misma clase. Parece razonable decir que una pintura debe realizarse primero en un ejemplar, antes de existir como tipo; un primer ejemplar establece el tipo, del cual pueden derivarse otros ejemplares. De la misma forma, un primer artículo debe ser escrito por un autor, antes de que se establezca un tipo, que haga el papel de pauta directiva para los diferentes ejemplares que luego sean creados. Con los fonemas, las palabras, las notas musicales, etc., no ocurre esto de la misma manera: aquí no existe la primera "l" que crea el tipo que luego se repite. Ciertamente, sería posible determinar cuando el fonema, o en todo caso la palabra, se usó por primera vez, pero normalmente esto no es relevante para el que habla. En la medida que se vuelve relevante, la tipicalidad, con esto, cambia de carácter.

Se puede hablar de relaciones temporalmente ligadas $o$ no ligadas entre tipo y ejemplar; en el primer caso, pero no en el último, se establece el tipo en el tiempo mediante la creación de un primer ejemplar (Sonesson, 1997b; 1998a). Obsérvese que aquí se trata de otra distinción que la que Goodman hace entre artes autográficas y alográficas. Entre las diversas tipicalidades ligadas temporalmente que habíamos señalado con anterioridad, el texto verbal es alográfico, mientras que la obra de arte es tradicionalmente autográfica; en otras palabras, la obra de arte, pero no la literatura, es definida en la práctica social que hemos heredado, tanto en su identidad como en su valor, por su asociación temporal al primer ejemplar creado por un individuo determinado. Por eso, tenemos que hacer cola frente a la Biblioteca Nacional para ver el único ejemplar de "Don Quijote", conducta que también se espera de nosotros ante una obra de arte. Aquí aparece toda la jerarquía social de valores: la radicalidad de los primeros ready-made que Duchamp exhibió, no consistía en tratar una tipicalidad temporalmente

$\overline{\text { Significação } 20 \bullet 100}$ 
ligada como si no lo fuera. En realidad, el seca-botellas y el mingitorio dependen también de tipicalidades temporalmente ligadas. Descansan en un género de prototipos. La diferencia radica en los diferentes valores atribuidos al primer ejemplar que crea el tipo en la producción del objeto de uso o de la obra de arte.

Naturalmente, sería erróneo comparar la imagen informática con el idioma en este sentido: es, como todas las imágenes, una tipicalidad de temporalidad ligada. En realidad, es la computadora misma la que pone la fecha y hora a la imagen en su momento de creación; pero aunque sepamos cuándo se ha creado la imagen, es más difícil saber dónde se ubica. El carácter esquivo del primer ejemplar hace especialmente absurdo persistir en un punto de vista autográfico en el caso de la imagen informática.

\section{Más allá del índice en la fotografía}

Desde hace mucho tiempo ya, la fotografía ha sido la manera moderna de crear una imagen; ha sido la manera rápida de hacerlo, por ser mecánica; también ha sido una manera fácilmente repetible; y finalmente, ha sido la manera veraz, la única manera para la imagen de permanecer fiel a la realidad, a su objeto así como a su causa. Por otro lado, la fotografía ha adquirido la reputación de estar privada de alma, siendo incapaz de revelar las características personales de su autor. En estos últimos días de la era de la fotografía, sin embargo, en los cuales finalmente ha ganado su aureola, la teoría ha acabado por alcanzar a la invención, llamando a la velocidad, tecnografía: a la capacidad de repetición, tipicalidad; a la veracidad, indexicalidad; y a la carencia de alma, falta de ilocucionaridad.

El mundo postfotográfico puede existir solamente en el mismo sentido en que ya hemos desde hace bastante tiempo vivido en el mundo después de la pintura: un mundo en el cual el significado de la pintura ha sido modificado por el advenimiento de la fotografía. Pero ahora el significado de la fotografía y de la pintura está igualmente en proceso de ser cambiado fundamentalmente por la aparición de la imagen de computadora. 


\subsection{La indexicalidad fotográfica como abrasión restringida}

Contrariamente a la mayoría de las otras categorías de la imagen, la fotografía ya ha dado lugar a un pequeño conjunto de publicaciones preocupadas por describir la especificidad de su función de signo (cf. Sonesson, 1989b; 1994c). Según Philippe Dubois (1983:20ff), las primeras teorías semióticas de la fotografía tendieron a tratar ese tipo de imagen como un espejo de la realidad, o, en los términos de Peirce, como un ícono; luego vino la generación célebre de los iconoclastas que intentaron demostrar la convencionalidad de todos los signos, llegando hasta ver incluso en la fotografía una versión "cifrada" de la realidad, o, como lo hubiera dicho Peirce (según Dubois, por lo menos) un símbolo; y finalmente la fotografía fue reconocida por lo que realmente es, en la opinión de Dubois: un índice, más específicamente, una huella dejada por el pasaje del referente mismo. La vuelta explícita a una posición indexicalista fue tomada más o menos por el mismo tiempo por Dubois, Henri Vanlier (1983) y JeanMarie Schaeffer (1987; cf. Sonesson 1989b:46ff). Aunque Dubois y Schaeffer se refieren explícitamente a Peirce al introducir la idea de indexicalidad, no se preocupan por especificar este concepto, ni por determinar en qué medida puede todavía ser considerado como válido. A nosotros también nos falta aquí el espacio para entrar en todos los detalles de la noción de indexicalidad (pero véase Sonesson 1989b, 1995b, 1998c, 1999a, 2001), pero vamos a estudiar unos aspectos que tocan más directamente a la naturaleza de la fotografía.

Para empezar, no se puede dividir al mundo en "cosas" por sí separadas como íconos, índices, y símbolos: la indexicalidad, tal como se aplica a los signos, es una relación, y por lo tanto, dos entidades (que podemos llamar aquí expresión y contenido, para no complicar las cosas inútilmente) pueden entrar en esa relación, sin excluir la posibilidad de que también participen en las relaciones de iconicidad y de simbolicidad, sea de manera mutua, o cada una en relación a otras entidades. Por lo tanto, no se trata en absoluto de determinar si la fotografía es icónica, indexical o simbólica. Más bien 
hay que establecer la configuración particular de estas relaciones en el signo fotográfico.

Ahora bien, como todos los que han leído a Peirce saben, la iconicidad en sí misma ni siquiera es una relación, porque implica una sola entidad (es una primaridad): cuanto mucho, es una lista de los propiedades de una cosa que percibimos de manera "inmediata" Como secundaridad, en cambio, la indexicalidad es inmediatamente una relación, pero ni siquiera esta relación se identifica con la relación del signo. En unos de sus textos, Peirce habla del fundamento ("ground") que es el punto de vista desde el cuál la expresión representa al contenido (2.228). Según nuestra interpretación, el fundamento constituye el momento en el cuál la iconicidad se vuelve relación, o sea secundaridad. Por lo tanto, Greenlee (1973:64) no tiene enteramente razón cuando identifica al fundamento con el aspecto pertinente del contenido, por ejemplo, el viento en el caso de la veleta, y tampoco lo tiene Savan (1976:10), que lo identifica con un aspecto de la expresión, o sea, en el caso de la veleta, la propiedad de moverse en la dirección del viento. Podríamos igualmente decir que los dos tienen razón, porque, a nuestro modo de ver, el fundamento implica a la vez a la expresión y al contenido. Sin embargo, quisiéramos insistir en la doble referencia del fundamento, porque es una relación, una secundaridad. De hecho, Peirce mismo dice que el fundamento es una abstracción y da como ejemplo lo negro de dos cosas negras (1.293). Se trata entonces de un fundamento icónico, mientras que el fundamento de la veleta es indexical.

Si la propiedad que caracteriza a la iconicidad, cuando se vuelve signo, es la semejanza, la indexicalidad deriva, por su parte, de la "conexión real" o de la "existencia en común", según unas expresiones que encontramos en la obra de Peirce. ${ }^{1}$ Si ubicamos las relaciones indexicales en el mundo real en que vivimos, el mundo de la vida, podemos concebirlas en términos espaciales: se trata de la

1. En los escritos de Peirce se encuentra también una definición involucrando a la causalidad, y es por supuesto la versión que más interesa a Dubois. Pero hemos demostrado en otro lugar que esa definición no es suficientemente general para dar lugar a una descripción exhaustiva del universo de los signos, junto con los dos otros tipos de signos caracterizados por Peirce.

Significação $20 \cdot 103$ 
contigüidad, o de relaciones entre la totalidad y sus partes (que vamos a llamar factoralidad en lo que sigue). La veleta se determina por la contiguiidad, como lo hace también la huella dejada por un animal en el bosque. Pero el pedazo de papel que, en un ejemplo de Peirce, sirve para resolver un crimen, se vuelve signo por su referencia a la parte que falta, o sea gracias a la factoralidad.

Cuando se dice que una fotografía es indexical, no se puede tratar de factoralidad, sino de contigüidad, y, más aún, de una contigüidad de tipo especial: la abrasión, es decir la relación indexical particular resultante del hecho de que el objeto que ha de convertirse más tarde en el referente ha estado, en un momento anterior en el tiempo, en contacto con lo que vendrá más adelante a convertirse en el plano de expresión del signo, para separarse después de ese, dejando en su superficie un rastro visible, aunque tal vez discreto, del acontecimiento (cf. Sonesson 1989a, 40; 1989b:46ff). En realidad, como lo anota Vanlier (1983:15), la fotografía debe ser considerada como una impresión directa y segura de los fotones, es decir de la luz emitida por los objetos representados, y solamente como una impresión indirecta y abstracta de los objetos mismos. Desafortunadamente, Vanlier (1983:23,25) mismo parece rápidamente olvidarse de esta distinción fundamental, porque habla de la escena en el mundo real como la causa de la imagen. En cualquier caso, no saca la conclusión esencial que se impone: si la indexicalidad en cuestión es una relación entre los fotones y la placa fotográfica, no aparece entre los mismos objetos que la función semiótica, es decir las cosas representadas y la imagen. Por lo tanto, no sirve para definir la fotografía. Dubois (1983:66) se muestra por lo menos más coherente con su propio concepto de fotografía como un índice cuando considera el fotograma como el caso más característico; sin embargo, si éste es el tipo de fotografía que quiere explicar, nunca llegará a caracterizar lo que la mayoría de la gente considera como una fotografía prototípica, es decir, una imagen en la que se puede reconocer la realidad representada.

La base, en la cual se inscribe la huella fotográfica, impone ciertas limitaciones. Algunas de éstas son mencionadas por Vanlier: 
la forma cuadrangular de la imagen, su naturaleza digital, la información que omite, su incapacidad de registrar los aspectos temporales del proceso que da lugar al rastro, etc. Resumiendo estas observaciones se puede decir en forma modificada que la fotografía no sirve solamente como una indexicalidad de los objetos, o incluso los fotones, sino también como una indexicalidad de las características de la película, de las lentes, del dispositivo fotográfico generalmente, del espacio atravesado por los fotones, etcétera. De una manera paralela se dice en un estudio de las huellas de diferentes animales, que el mismo animal dejará marcas diversas según la naturaleza de la tierra que cruza. Ennion y Tinnbergen (1967:16) hacen notar, por ejemplo, que mientras la víbora "'nada' como una anguila en el agua" sobre la mayoría de las clases de tierra, produciendo cierto tipo de dibujo, su manera de avanzar en la arena plana resulta en una serie de crestas en ángulo oblicuo a la dirección de la huella, absolutamente diferente del patrón anterior. Significa que el mismo objeto, y la misma parte o noema apropiada del objeto, producen diversas impresiones en diversas tierras. De la misma manera, la "imagen acústica" y el termograma de la mano tienen poco en común con una imagen regular de la misma mano. Es decir, la huella dejada en la tierra no es realmente un resultado directo del pie que la toca, sino de la interacción del pie con la tierra.

El problema con una definición puramente indexicalista de la fotografía es que no puede explicar de qué es la fotografía una imagen. No hay razones intrínsecas para considerar que la causa que produce una huella (y incluso así, hemos visto que muchas más causas que el referente se puede poner en relación con la huella) es un tipo más importante de causa que las otras. En realidad, solamente podemos explicar la importancia de la escena representada, cuando entendemos que una huella, en el sentido más central del término, contiene no sólo aspectos indexicales sino también aspectos icónicos, y si comenzamos admitiendo que una fotografía es una clase de signo llamado imagen y que todos los signos de esto tipo dependen fundamentalmente de la ilusión de semejanza. Es lo que caracteriza a toda la clase de lo que Maldonado (1974) llama "íconos duros", como las imágenes de rayos $\mathrm{X}$, las impresiones de manos en las paredes de 
las cuevas prehistóricas, las “imágenes acústicas" producidas con la ayuda del ultrasonido, siluetas, configuraciones dejadas en la tierra por la gente que estaba afuera caminando en Hiroshima en el momento de la explosión de la bomba nuclear, termogramas, imágenes creadas con "luz invisible" para descubrir a personas ocultándose en el bosque, etc. Según Maldonado, la contigüidad real entre la imagen y su referente sirve para garantizar el valor cognoscitivo de la imagen. Pero es importante observar que los "íconos duros" no pueden simplemente ser todos los signos que son a la vez indexicales e icónicos, porque eso se aplica también a las quirografías: debe haber coincidencia entre sus fundamentos indexicales e icónicos respectivos. En la fotografía, como hemos visto, incluso esto no es válido más que en un sentido bastante indirecto.

Contrariamente a Vanlier y a Dubois, Schaeffer (1987:101ff) piensa que la fotografía puede ser un ícono indexical en algunos casos, y, en otros casos, un índice icónico. Da así la impresión de ser menos rígido en su indexicalismo que Vanlier y Dubois. Uno podría sostener, sin embargo, que la fotografía, contrariamente, por ejemplo, a la huella de un casco, es siempre sobre todo un ícono (Sonesson, 1989b:68ff). Mientras que la fotografía y la huella de un casco representan a un referente que ha desaparecido de la escena, el significante del último signo continúa ocupando el lugar que era el del referente y sigue siendo ubicado en el tiempo, mientras que el significante fotográfico, como el del signo verbal, es omni-temporal y omni-espacial, y forma un tipo cuyos ejemplares pueden ser realizados en cualquier momento y lugar (aunque solamente después del acontecimiento de referencia y del tiempo necesario para el desarrollo). En resumen, en el caso de la huella de un pie, y de un casco, etc., la expresión y el contenido están situados en un lugar y un momento particulares; en la lengua verbal, ni la expresión ni el contenido están temporal y espacialmente limitados; y en el caso de la fotografía, es solamente el contenido (o, en sentido estricto, el referente) que está limitado por la espacio-temporalidad. Así, la huella del casco, presente donde antes el caballo estuvo presente, nos dice algo como "caballo aquî"; pero la fotografía de un caballo, que probablemente no ocupa la escena donde antes estaba el caballo, 
sólo nos dice "caballo" y después podemos comenzar a reconstruir el tiempo y el lugar.

Al llegar a este punto, parecería posible decir que, mientras que la huella del casco es primero un índice, la fotografía debe considerarse principalmente como un ícono, antes de que puedan ser descubiertas sus características indexicales. En realidad, sin embargo, las cosas pueden ser todavía más complicadas. Schaeffer tiene por supuesto razón en precisar, contra Peirce, que no todos los índices conllevan un cierto aspecto icónico, pero es cierto que las huellas de los cascos, exactamente como todo tipo de impresiones y de huellas, en el sentido estrecho de estos términos, también manifiestan una semejanza parcial con los objetos que representan. Tenemos que reconocer las huellas de cascos como tales, es decir, distinguirlas de las huellas de los pies humanos, o de los cascos de los asnos, así como de las huellas de cascos falsos, y de las formaciones accidentales producidas por el viento en la arena. No es sino hasta después que podemos interpretar las huellas de cascos de una manera indexical. Sigue siendo verdad, sin embargo, que los significados esenciales de las huellas de cascos derivan de la indexicalidad: nos hablan del lugar donde estuvo el animal.

En el caso de una fotografía, por otra parte, no necesitamos concebirla de manera indexical para poder captar su significado. Continuará comunicándonos su significado, si estamos seguros que es una fotografía o no. La indexicalidad, en la fotografía, realmente es una cuestión de los pensamientos secundarios y de las circunstancias peculiares. Así, la relación entre la superficie de la imagen y el referente funciona sin ninguna duda como una relación de signo cuando un espía intenta descubrir construcciones militares secretas en una fotografía aérea o cuando una fotografía se utiliza para decidir quién, entre un número de corredores, ganó la competencia; no hay que olvidar que las mismas fotografías se pueden considerar como imágenes por su propia cuenta, sin tematizar la relación indexical. Aunque la indexicalidad fotográfica es una indexicalidad de la luz, no es la mayoría del tiempo más central en la interpretación de fotografías que la indexicalidad de los dibujos. Por lo tanto aparece que la indexicalidad no puede ser la relación primaria de 
signo de las fotografías, aunque sea una potencialidad abierta presente en su constitución, que se explota en ciertos casos. La fotografía es en primer lugar un signo icónico. En el sentido de la escuela de Praga, la iconicidad es el dominante del signo fotográfico, usando la indexicalidad para sur propias metas.

\subsection{Sistemas globales y locales de transposición}

En la historia de la semiótica fotográfica según Dubois, Barthes aparece como un protagonista de la concepción icónica, porque puso el carácter convencional, históricamente relativo y aprendido del dibujo en oposición a la naturaleza "casi-tautológica" que muestra la expresión fotográfica en relación a su contenido. Aparece también como un vindicador de la interpretación de la fotografía como símbolo probablemente a causa de su lista de "connotaciones fotográficas", y es considerado como un pionero de la teoría del índice porque ha descrito una fotografía como implicando la afirmación "esto ha ocurrido" ("cela a été"). En realidad, también Peirce se puede considerar como un representante de estas tres concepciones: a veces nos dice que la fotografía es un índice, a veces un ícono, y por otra parte observa que todos los íconos reales tienen algo de convencional.

Considerada de más cerca, la defensa de la interpretación icónica por Barthes (1964) puede muy bien resultar menos ingenua de lo que se ha dicho últimamente. Podría ser interpretada como la teoría según la cuál el dibujo, pero no la fotografía, requiere la existencia de un sistema de reglas que permitan transponer la experiencia perceptiva a unas marcas producidas por una pluma sobre un papel; y según la cuál estas reglas implican una segmentación particular del mundo accesible a la percepción, que consiste en escoger algunas (clases de?) características para la reproducción, mientras otras se rechazan, y quizás acentuando algunas características al mismo tiempo que otras retroceden al fondo; y todo esto ocurriendo bajo circunstancias históricas dadas, que son responsables de la variación de los énfasis y de las exclusiones. Contra esto, se puede sostener que la perspectiva del 
Renacimiento y muchos otros principios de representación, son intrínsecos a la cámara fotográfica: pero precisamente están incorporados al aparato, y así no se perciben conscientemente en el proceso real de la producción de la imagen.

La idea llega a ser más razonable cuando se expresa como una diferencia entre los tipos de reglas de transposición implicados en la fotografía y en las imágenes hechas a mano, respectivamente. Si consideramos la relación entre el contenido de la imagen y su referente en el mundo exterior como un tipo de indexicalidad, más exactamente como un género de factoralidad (una relación de la parte a la totalidad), podemos interpretar lo que dice Barthes como sigue: la fotografía puede aislar unas partes particulares ("son sujet", "son cadre") así como unas perspectivas ("son angle") del motivo entero, pero no puede escoger de dar cuenta de nada más algunas de sus cualidades. En un sentido obvio esa afirmación sigue siendo falsa: por razones esenciales, la fotografía transmite solamente características visuales y rinde solamente las características que se presentan a los lados del objeto que están directamente enfrente de la cámara fotográfica. Además, dependiendo de la distancia entre la cámara fotográfica y el motivo, solamente las características contenidas en una gama particular de tamaños pueden ser incluidas.

Si hacemos excepción de la fotografía alterada con trucos, sin embargo, parece cierto que, sin tener recurso a una modificación ulterior de la placa expuesta, la fotografía solamente es capaz de aislar características, o de restringir su selección de características, a nivel global, mientras que en el dibujo, las decisiones locales se pueden tomar para cada una de las características separadamente (cf. Sonesson 1989b:36ff; Dubois 1983:96f). Esto también vale para las demás reglas de transposición fotográfica enumeradas por Ramírez (1981:158ff) y Gubern (1974:50ff): la abolición de la tercera dimensión, la delimitación del espacio a través del marco, la exclusión del movimiento, la visión mono-focal y estática, la estructura granular y discontinua del plano de expresión, la abolición o la distorsión del color, la limitación a las escenas que tienen cierta gama de luminosidad, y la eliminación de estímulos no visuales. 
Nuestra fórmula puede contribuir a iluminar unos casos que a primera vista parecer ocupar una posición intermedia entre la fotografía y la quirografía. Durante el siglo XVIII, un dispositivo para producir dibujos a partir de siluetas estuve en uso: consistió en una silla que tenía una fuente de luz a un lado y una pantalla en la cual la sombra de la persona que se sentaba en la silla se proyectaba al otro lado. Los contornos fueron transferidos a la pantalla por medio de la contigüidad. No se conservaron por sí mismos ningunas marcas de los contornos en la pantalla, debido a la carencia de una emulsión fotográfica, sino las marcas tuvieron que ser completadas a mano. En el caso del curioso dispositivo conocido como physionotrace, un visor se movía a lo largo de los contornos del objeto, produciendo una contigüidad entre estos contornos y la mirada en movimiento; y gracias a otra contigüidad, esta vez entre el visor y una aguja, la figura correspondiente fue inscrita al mismo tiempo sobre un papel. De una manera semejante, en la cámara obscura utilizada por los artistas a partir del Renacimiento, había una serie de contigüidades entre los contornos del objeto y la configuración de luz en el papel, y entre la configuración de luz y los trazos correspondientes a los contornos creados por la luz.

En todos estos casos, hay semejanza y contigüidad entre la expresión y el referente, y aunque la contigüidad es mediada, esto también es verdad, como hemos visto, en el caso de la fotografía. Sin embargo, en la cámara obscura y en el dispositivo para fabricación de siluetas, el paso de la configuración luminosa al trazo no es determinado mecánicamente sino que la decisión de hacer corresponder el segundo al primero es un acto libre de la voluntad. De manera semejante, en el physionotrace, la decisión de seguir los contornos del objeto con el visor es un acto libre, incluso si todo lo demás sigue mecánicamente de esa decisión. En la cámara fotográfica, por otra parte, el sistema entero de la decisión se pone supuestamente en ejecución mecánicamente, y eso es lo que constituye la garantía decisiva de la autenticidad.

Visto de esta manera, las imágenes producidas por el ordenador parecen plantear un problema. De una manera bastante 
indirecta, la contigüidad tiene un papel en la creación de ciertas imágenes de computadora: el ratón de la computadora y más obviamente el tablero de dibujo digital, son claramente dispositivos manuales que dejan huellas sobre una superficie, aunque esta superficie no sea directamente el monitor, y todavía menos el papel impreso. A pesar de que la noción misma de superficie se vuelve dudosa en este caso, es ciertamente verdad que moviendo el ratón, creamos una anotación de un tipo de abrasión, que puede ser incluso producido accidentalmente por un niño o un gato más interesados en el movimiento por sí mismo. La abrasión no resulta de la presión física (con excepción de la primera fase en la cual la mano agarra el ratón y lo presiona al tablero del escritorio) o de la luz, sino de impulsos electrónicos.

Sin embargo, las imágenes producidas, no por medio de un ratón o por otro tipo de dispositivo manual, sino creadas enteramente o en parte por algoritmos matemáticos, no parecen involucrar la indexicalidad de ninguna manera esencial. Por otra parte, los 3Dscanners no sólo se valen enteramente de la indexicalidad, sino también suponen una coincidencia entre el fundamento indexical y la función de signo, de una manera que hace pensar en la fotografía, y quizás aún más en el physionotrace.

En cuanto a la relación indexical de la factoralidad entre referente y contenido en las imágenes de computadora, parece ser idéntica al tipo encontrado en las imágenes quirográficas: la continuidad es sugerida por lo que sabemos de las conexiones que existen en nuestro Lifeworld socio-cultural, no por nuestro conocimiento de ciertos objetos individuales sacados de la experiencia de la vida real. Sin embargo, las connotaciones fotográficas comunicados por algunas imágenes de la computadora tienen tendencia a sugerir que algunos objetos del mundo real han estado presentes alrededor de la cámara fotográfica, y no solamente delante de ella.

Por más falsa que sea la connotación de lo fotográfico (y desde luego la correspondencia con la realidad) en las imágenes sintéticas, es sin embargo menos turbia. Nada, sino el posible carácter extraño del objeto, parece separar estas imágenes de la fotografía verdadera. No obstante es posible, como señala Moles (1971:54; 1981: 
29), construir el objeto a partir de su imagen y posteriormente arreglar la imagen de acuerdo a la realidad. En la práctica socialmente heredada de lo fotográfico, la fotografía es un testigo de la verdad y esta función se traslada a la imagen sintética, cuyo plano de expresión no se deja distinguir del de la fotografía. Y así puede seguir siendo hasta que un día la imagen sintética llegue a ser tan común como la fotografía; entonces, estaremos obligados a abandonar esta presuposición que se aleja cada vez más de la existencia de una relación anterior de cercanía entre el motivo y la imagen. $\mathrm{O}$ si no, debemos descubrir cualidades más sutiles que nos ayuden a separar las dos categorías de imagen.

\subsection{La tela de la causalidad y de la intencionalidad}

De cierta manera, Schaeffer es un indexicalista más radical que Vanlier y Dubois: piensa que declarando a la fotografía como indexical, e identificando indexicalidad con causalidad, uno puede eliminar totalmente las intenciones del fotógrafo. Para demostrarlo se refiere al caso extremo de una cámara fotográfica ubicada directamente delante de la línea de meta, de manera tal que se accione automáticamente cuando los caballos cruzan la línea. La fotografía se produce en apariencia de manera que ningún agente humano, intervenga.

En nuestra opinión, sin embargo, el ejemplo de Schaeffer no demuestra lo que sostiene. En realidad, el hecho mismo de montar la cámara fotográfica en este lugar particular, dirigiendo el objetivo en una dirección particular, e instalando cierto mecanismo que accione la cámara fotográfica cuando los caballos crucen la línea de meta, implica que alguien ha dado expresión a un sistema de intenciones incluso si puede haber razones por llamarlas intenciones alejadas. Esta observación también se aplica al caso de una cámara fotográfica montada en un vehículo enviado por un cohete a Marte, para tomar fotografías de la superficie. Es posible que ni siquiera la dirección en la cual las imágenes se toman en un momento particular se puedan determinar por un agente humano cualquiera, pero sigue siendo verdad que alguien tiene que haber tenido una intención al construir 
el dispositivo y mandarlo a Marte. Por otra parte, es verdad que, para la mayor parte de los propósitos, podemos dejar de tomar en cuenta las intenciones de los fotógrafos, exactamente como podemos ignorar las causas por las cuales algunos objetos han dejado sus huellas en la emulsión fotográfica, excepto en casos tales como la fotografía de la línea de meta y el de la fotografía del espía.

Tradicionalmente y, más recientemente, en la teoría semiótica y en la pragmática, a menudo se hace una oposición neta entre los dibujos y las fotografías en respecta a la intervención de la intencionalidad. Al discutir la contribución que hace el otro al conocimiento sobre nosotros mismos, Bakhtin (1990:34ff) sostiene que un retrato pintado, pero no una fotografía, nos comunica el punto de vista de otra persona sobre la persona retratada. Para Bakhtin, una imagen, exactamente como una obra de arte literaria, consiste en un objeto (un referente) y un punto de vista aplicado sobre ese objeto (su "entonación" o "acentuación"). No obstante, niega que una fotografía se pueda analizar de esta manera: es puramente material, no es el punto de vista de nadie. Esto concuerda con la concepción defendida por Barthes, según la cual la relación entre el significante y el significado en la fotografía es "tautológica", así como con la teoría indexicalista de la fotografía, como la formula, por ejemplo, Schaeffer. Sin embargo, hemos visto que la fotografía supone en realidad una serie de reglas para transformar aspectos perceptivos en marcas sobre la superficie de la imagen, que por supuesto son intrínsecos en parte a la cámara fotográfica, pero también están en parte determinadas por la posición tomada por el fotógrafo, los ajustes que hace a la cámara, etcétera. La verdadera diferencia consiste en el carácter global de las reglas fotográficas de transposición, en comparación con las muchas decisiones locales de las cuales las imágenes quirográficas dependen. Es como decir que cada detalle de las imágenes quirográficas tiene su punto de vista particular, mientras que en el caso de la fotografía solamente la totalidad comunica un punto de vista.

De manera similar, Grice (1989:218) opone el caso en el cual se enseña a alguien una fotografía de su esposa sorprendida en una relación adúltera con otro hombre al caso en el cual se le enseña 
la misma situación en un dibujo. Grice piensa que solamente en el último caso la imagen significaría algo, porque la fotografía produciría el mismo efecto, a su entender, si el marido la encontrara en el cuarto de manera accidental. El argumento de Grice depende obviamente de la idea de que una intención de comunicar algo tiene que ser reconocida para que exista una significación; pero para nuestros propósitos podemos transformar esto en la tesis según la cual un dibujo, pero no una fotografía, justificaría la atribución de una intención a la persona que lo produce, mientras que la fotografía solamente nos permite asignar una causa a la fotografía que enseña la escena relevante. Debemos por supuesto excluir la posibilidad de que la imagen que parece ser una fotografía en realidad sea un documento creado por un programa gráfico de computación.

No obstante, nos parece que la diferencia no es tan nítida como Grice afirma. Incluso si el marido encontrara accidentalmente un dibujo, en vez de una fotografía, enseñando a su esposa en una situación comprometedora, estaría tal vez muy preocupado; porque debe probablemente haber alguna "causa", en el sentido más amplio del término, por la cual el dibujante ha escogido reproducir esta escena, y esta "causa" puede muy bien ser el hecho de haberla observado.

El ejemplo de Grice es especial, porque se refiere a la interpretación de la situación reproducida por el signo, el referente, en lugar del signo mismo. Por lo tanto, es necesario preguntarse cómo separaríamos las partes que tienen que ver con la intención y la causalidad, respectivamente, en un signo considero por sí mismo, tal como una obra de arte. En el caso de una fotografía creada por un no-profesional, el hecho de que muchos de los objetos representados estén cortados en los márgenes de la imagen normalmente se considera como algo no intencional, en realidad, un efecto causado por la maestría limitada del fotógrafo. Pero en los trabajos de CartierBresson, este aspecto es esencial para definir su estilo peculiar de la fotografía "en flagrant délit" Una razón para verlo así es que hemos interpretado ya las fotografías de Cartier-Bresson como obras de arte. Otra razón puede ser la consistencia con la cual estas características se repiten en los trabajos realizados por este fotógrafo (No obstante, esto puede también ser el caso de algunos fotógrafos no 
profesionales). Otra razón más, sin embargo, puede ser que CartierBresson nos haya declarado sus intenciones por medio de otros sistemas semióticos.

Pragmatistas como Grice sostienen que la intención del hablante es parte de lo que debe captar cualquier persona que desea entender una elocución dada. Reformulado en términos semióticos, corresponde al postulado que la intención (o lo que es el portador de la intención) es parte del plano de la expresión del signo. Es decir, según esta manera de ver, para entender que una expresión E significa $C$, no es suficiente reconocer que $E$, según un sistema de interpretación, está en lugar de $\mathrm{C}$, es necesario captar que hay alguien $\mathrm{S}$, que tiene la intención $\mathrm{I}$, de significar $\mathrm{C}$ (o $\mathrm{C} 1$, etc.) al usar $\mathrm{E}$, etcétera. Contra esta concepción, hemos sostenido que la intención se debe, al contrario, entender como parte del contenido de cierto sistema semiótico, tal como el lenguaje verbal (cf. Sonesson 1999b; 2002); más exactamente es parte de lo que Hjelmslev llama la connotación del signo, es decir, una significación que resulta del hecho de que el hablante elige una expresión en vez de otra que también es posible para representar a cierto contenido, o una variedad en lugar de otra de la expresión (cf. Sonesson, 1989a:79ff). Simplemente, es parte de nuestras convenciones o hábitos de atribuir intenciones a la configuraciones visuales que se asemejan a letras, así como a sonidos que se asemejan a fonemas. En cambio, otros signos, tales como los gestos (con algunas excepciones) se consideran normalmente como signos no-intencionales.

Para entender que una expresión $\mathrm{E}$ significa $\mathrm{C}$, tenemos que reconocer solamente que $\mathrm{E}$, según cierto sistema de interpretación, representa a (denota) $\mathrm{C}$; si, además, reconocemos que $\mathrm{E} / \mathrm{C}$ es parte del (connota al) lenguaje verbal, que es un sistema semiótico que en el curso ordinario de acontecimientos suponemos que sea producido por agentes (más o menos) conscientes y dirigidos por metas, pensaremos que la razón de que $\mathrm{E}$ sea producido en este momento particular, es que un agente $\mathrm{A}$ desea comunicar nos $\mathrm{C}$, además de su intención de comunicarnos $\mathrm{C}$, etcétera. $\mathrm{Si}$ encontramos unas figuras en la arena dentro del desierto que parezcan letras, no las podríamos interpretar como tales, según dicen los pragmatistas, porque si sabemos 
que no hay gente en la cercanía, no podemos atribuir intenciones a esas formas. En realidad, no es así: si las formas son suficientemente parecidas a letras, no podemos evitar de sacar la conclusión, que o bien, a pesar de nuestras suposiciones anteriores, sí hay o ha habido antes gente en el desierto, o bien que se trate de un mensaje producido por "el mano de Dios" Por lo tanto, las formas son primarias. Las intenciones se atribuyen solamente en consecuencia a las formas.

A partir de lo que se ha dicho sobre las fotografías y los dibujos arriba, debe quedar claro que esta concepción, como se ha presentado hasta ahora, es demasiado simple. No es verdad que los sistemas semióticos puedan ser distinguidos en sistemas cuyas realizaciones se interpreten como intencionales, y otros no: más bien habría que decir que diversos esquemas de interpretación permiten la atribución de intenciones a niveles más o menos bajos en la estructura formada por las configuraciones integrantes; y que pueden permitir que la intencionalidad sea asignada en unas etapas más o menos alejadas de la selección. En el lenguaje verbal, no consideramos normalmente la concordia gramatical obligatoria como el resultado de una decisión muy consciente para el hablante cuando usa su lengua materna. Por lo tanto, hay un punto en la estructura de la lengua donde la intencionalidad ya no es automáticamente atribuible. Levinson (1983:11) se pregunta en qué sentido se podría afirmar que quién dice "Je suis malheureuse" tiene la intención de comunicar que es una mujer. Esta intencionalidad se podría por supuesto atribuir al hablante, en la medida en que "se ha hecho cargo" (en el sentido de Benveniste) de las reglas del idioma francés; sería una intencionalidad alejada. Tal atribución tendría más sentido si hubiese una opción posible entre varios dialectos. También tendría más sentido, si un hombre usase la frase, para construirse una personalidad femenina.

Cuando reconocemos algo como fotografía o dibujo, significa que hemos podido asignarlo a un esquema particular de interpretación que puede a menudo bastar para determinar la parte de causalidad y de intencionalidad implicadas, lo profundamente intrincadas que están en la estructura de los signos, así como su grado de alejamiento. A veces, por supuesto, pueden ser necesarias informaciones adicionales (es decir otros esquemas de interpretación) 
para determinar los niveles de intrincación particular de la estructura y del alejamiento de la historia de los cuales se pueden atribuir intención y la causalidad a los signos. Pero es exactamente tales esquemas de interpretación que parecen no ser válidos con el advenimiento de la imagen de computadora.

\section{La imagen como doble y realidad}

\subsection{La indeterminibilidad de la superficie}

Considerada como imagen, la imagen informática tiene algo de paradoja: su superficie no es fácil de encontrar. Dijimos, como Gibson, que la imagen es una superficie provista de marcas. Una vez impresa, la imagen informática es esa superficie, es decir, una hoja de papel, tal como un dibujo o ciertas pinturas y sus marcas son manchas de carbón producidas por el cabezal impresor. Mientras que la imagen se muestra en la pantalla de la computadora es ésta una proyección de sombras, igual que la imagen de vídeo, y no tan diferente de la diapositiva o la proyección de la linterna mágica. Pero ¿Dónde está la imagen y cuál es su superficie cuando no se muestra en la pantalla o no está impresa? O en otras palabras, ¿Dónde está la imagen original de la cual tanto la impresión como la imagen de la pantalla son copias?

El problema con el que nos hemos encontrado al confrontar la definición de la imagen según Gibson con la imagen informática, Gubern lo ha encontrado también (1987a:83s) por otros caminos. Antes de la era de la computadora, afirma, la imagen exigía una base lisa y dura en la cual el mensaje se inscribía en forma permanente a mano o con medios químicos. Esto era válido para la pintura, el grabado, la fotografía y el filme, pero dejó de ser así con la imagen de vídeo y la imagen informática. Ya el film y la diapositiva implican una disociación entre imagen y el fundamento que sirve para almacenarla; pero en estos casos, la imagen que se proyecta en la pantalla es igual en su conformación (isomorfa) a aquellas que aparecen inscritas gráficamente en el fundamento; se diferencian sólo en tamaño. Tanto 
en el caso de la imagen de vídeo como en el de la imagen informática falta este isomorfismo óptico entre el fundamento y la imagen proyectada.

La diapositiva es ya una superficie difícil de fijar (y de cierta manera lo son también el espejo, discutido por Eco, y la superficie del agua, de la que parte Gubern). Por una parte existe la superficie de celuloide, elaborada a partir de procesos químicos, que han dejado un sedimento de distintos pigmentos. Por otra parte existe la pantalla blanca, en la cual se proyectan sombras. La pantalla como tal es tan poco isomorfa como lo que se muestra como imagen de vídeo, igual de "borrable" - y sin embargo, es éste el lugar de nuestra percepción. La superficie que es concreta y (relativamente) permanente, es decir, la diapositiva misma que se pone en el proyector, no es la superficie donde la imagen aparece para la percepción. En realidad, desde la diapositiva empieza un proceso que llega a su desarrollo completo con la imagen televisiva y con la computadora: un acercamiento del proceso de significado de la imagen a un modelo clásico de comunicación de acuerdo al cual un mensaje es enviado en un tiempo y lugar determinados para ser recibido en un lugar y tiempo también determinados. Este modelo no se deja aplicar a la pintura al fresco que durante siglos espera a sus espectadores en el mismo lugar, o al cuadro que siempre cuelga en el museo o en la sala. Al igual que el mensaje linguiístico, el vídeo y la imagen informática son algo que se manifiesta en un determinado instante, rápido y pasajero, en un lugar determinado (Véase Sonesson, 1992 y 1995b).

Como siempre, el signo existe sólo cuando se percibe. No obstante en el caso de la imagen informática, ésta ni siquiera permanece esperando en alguna parte en un formato perceptible. Como cualquier otro genio de botella, debe invocarse cada vez que se quiere percibir.

A pesar de la identificación que hace Gubern entre la imagen de vídeo y la imagen informática, parece que la primera tiene un carácter relativamente más concreto. Cada vez que se pone el vídeo en el aparato de vídeo se muestra la misma película, del mismo modo. Pero la imagen informática se puede manifestar tanto en la pantalla como en la impresora. También se puede producir un "documento" en la computadora, que luego se copia a otro "documento" y con cambios insignificantes se convierte en otro original. El primero puede 
ser la base para una larga serie de impresiones, pero puede eliminarse más tarde, cuando el nuevo original está impreso en una nueva serie. El límite entre la copia y el original es curiosamente indeterminado. La superficie de la imagen informática es más difícil de fijar que todas las demás. Tal vez quisiéramos identificar el original con lo que vemos en la pantalla; aunque es posible conectar varias pantallas a una computadora, ubicadas en uno o varios lugares en el mundo de los sentidos.

La respuesta a esta pregunta sólo puede darse dentro del marco de una determinada práctica social. La realidad de la diapositiva es la proyección de la imagen, porque existe una práctica social por la cual la imagen de celuloide sólo es un medio y la proyección en la pantalla un objetivo. Si la utopía de la oficina sin papel se hubiera vuelto realidad, entonces la imagen sin fundamento también podría haber existido. La imagen en la pantalla pudiera haber sido lo más cercano a lo que se pudiera llegar a la imagen real que también fuera perceptible. En el mundo definido por la práctica social actual, es la impresión que la es la verdadera imagen informática. $\mathrm{O}$ mejor dicho, es el tipo inmaterial que se define por el conjunto de todas las impresiones.

\subsection{Una imagen más allá del signo}

Las posibilidades de variación libre de la imagen informática parecen contradecir su carácter tecnográfico. La dificultad de ubicar la superficie en la cual existen las marcas de la imagen la hace aparecer como una clase de imagen paradójica. No obstante, hay también un tipo de imagen producida con la computadora que parece estar al borde de perder su carácter de signo.

A diferencia de la escultura, los maniquíes, las figuras de cera, los espantapájaros, los juguetes, etc. que son un tipo de signo de identidad (véase Sonesson, 1989a, II.2.2.III.6 y 1992a, III.1.), el holograma es sin duda una imagen; ofrece una superficie en la cual "se ve" o "perceptivamente se imagina" una escena perceptiva real (véase Sonesson, 1989a, II.3.5.). La superficie y la escena están al mismo tiempo presentes para la percepción, al mismo tiempo 
conscientes, pero experimentadas como excluyéndose una a otra. Por el contrario, la escultura es un objeto por derecho propio que representa otro objeto pero del cual le faltan algunas características.

En el caso del holograma, la ilusión de la realidad es más fuerte que en otras imágenes, y hasta cierto punto se puede tener acceso a diferentes perspectivas del mismo objeto si el espectador deambula alrededor de él, tal como en una verdadera experiencia perceptiva. Sin embargo, la ilusión nunca es total; el carácter de la imagen - y con ello el carácter de signo - siempre se da al mismo tiempo en la percepción. Esto no quiere decir que una futura técnica holográfica refinada no pueda permitirnos camuflar el carácter de imagen.

El caso de la "realidad virtual" es aún más ambiguo. Las imágenes sintetizadas pueden ser expuestas de modo tal que formen la totalidad del mundo circundante (aparente) percibido por una persona. Al tiempo que la persona puede moverse o manipular un objeto a su alrededor, sus movimientos conducen inmediatamente a cambios en las imágenes que se le muestran. Esto es posible porque la computadora dispone de innumerables perspectivas del objeto sintetizado. De este modo se puede visitar una casa antes de que se construya, caminar por los corredores o salir y entrar de habitaciones que aún no existen, probar la factibilidad de una escalera, la disposición de puertas y ventanas, etc. Pese a su carácter de imagen inequívoca, en el sentido antes mencionado, la "realidad virtual" comparte características con el mundo cotidiano que forma el fundamento para todos los signos. El fundador de la filosofía fenomenológica, Edmund Husserl, ha descrito, mejor que nadie, la particularidad del mundo de la percepción ("el mundo de la vida"), ha señalado que ésta descansa en la sensación de que "siempre se puede seguir adelante"; ver objetos desde distintos ángulos, aproximarse al objeto para descubrir nuevas características, investigarlo en otras circunstancias. La realidad virtual, tal como el mundo manifiesto, tiene estas características.

Como todas las imágenes sintéticas, la realidad virtual precede a su (eventual) referente. Pero tiene (eventualmente) un referente; no es uno. Hasta aquí perdura la experiencia del carácter 
de signo; de algo dado directamente que no es temático y que apunta a algo indirectamente dado que forma el tema (véase Sonesson, 1989a, I.2.5, I. 4.2; 1992a, b). Sin embargo, el límite entre el signo y la realidad se vuelve más difuso.

\subsection{La función del signo}

Cuando Peirceanos y Saussureanos discuten sobre la presencia de dos o tres entidades en el signo, nunca se preguntan qué clase de objetos, definidos por qué tipo de características, están involucrados: ¿qué nos permite determinar si un objeto dotado de significación está compuesto de una expresión, o "representamen", y de un contenido, o "objeto"? Sin duda alguna, Peirceanos y Saussureanos convendrían en que la definición del signo tiene algo que ver con la fórmula clásica, citada a menudo por Roman Jakobson (1975): aliquid stat pro aliquo, o, como lo dice también Jakobson, de manera más sencilla, con "renvoi" o referencia. ¿Pero qué significa? ¿Y es suficiente? Es necesario dar cuenta de los criterios que deben cumplirse para que algo sea un signo, que tanto en la tradición Peirceana como en la tradición Saussureana forman parte de los presupuestos no sometidos a discusión. Esto se podría hacer combinando lo que dice Husserl sobre la apresentación (algo que está directamente presente sin formar el tema se refiere a algo que está indirectamente presente pero que sí forma el tema) y lo qué Piaget dice sobre la función semiótica (hay una diferenciación entre la expresión y el contenido, porque, por un lado, la una no se transforma continuamente en el otro y viceversa ni en el tiempo ni en el espacio y, por el otro, son percibidos como objetos de naturaleza diversa).

Según Piaget la función semiótica (que, en sus obras tempranas llamaba la función simbólica) es una capacidad adquirida por el niño entre los 18 y los 24 meses, que le permite imitar algo o a alguien fuera de la presencia directa del modelo, utilizar el lenguaje, hacer dibujos, participar en "juegos simbólicos", y tener acceso a las imágenes mentales y la memoria. El factor común subyacente a todos estos fenómenos, según Piaget, es la capacidad 
de representar la realidad por medio de un significante que sea distinto al significado. En realidad, Piaget sostiene que la experiencia que el niño tiene de la significación precede a la función semiótica, aunque entonces no supone una diferenciación del significante y del significado dentro del signo (véase Piaget, 1970). En varios de los pasajes en los que se ocupa de la noción de función semiótica, Piaget hace observar que los "índices" y los "sígnales" son posibles mucho antes de los 18 meses, pero sólo porque no suponen ninguna diferenciación entre expresión y contenido. El significante del índice es, según dice Piaget, un "aspecto objetivo del significado"; así, por ejemplo, la extremidad visible de un objeto casi enteramente oculto a la visión constituye el significante del objeto entero para el bebé, exactamente como las huellas de un animal en la nieve significan la presa para el cazador. Cuando el niño utiliza un guijarro para significar un caramelo, sabe muy bien la diferencia entre ellos, lo que implica, como Piaget nos dice, "una diferenciación entre el significante y el significado desde el punto de vista del sujeto mismo"

Piaget tiene toda la razón al distinguir la manifestación de la función semiótica de otras maneras de "conectar significados" empleando sus propios términos. Sin embargo, es importante observar que, mientras que el significante del índice se describe como un aspecto objetivo del significado, nos dice que en el signo y en el "símbolo" (es decir, en la terminología de Piaget, la variante convencional y motivada de la función semiótica, respectivamente) la expresión y el contenido se distinguen desde el punto de vista del sujeto. Podemos, no obstante, imaginar al mismo niño que, en el ejemplo de Piaget, utiliza un guijarro en lugar de un caramelo, teniendo acceso a una pluma para representar a un pájaro, o emplear un guijarro en lugar de una roca, sin confundir, la parte y la totalidad: entonces el niño estaría empleando un rasgo, que es objetivamente una parte del pájaro, o de la roca, mientras distingue el primero del segundo desde su punto de vista. Sólo en este caso estaría utilizando un índice, en el sentido en el que este término se emplea en la semiótica, es decir, en el sentido Peirceano.

El cazador, por otra parte, que identifica el animal por sus huellas, empleándolas después para descubrir qué dirección ha 
tomado el animal, con el fin de atraparlo, no confunde, en su manera de concebir el signo, la huellas con el animal mismo, porque en el caso contrario estaría satisfecho con las huellas. Por otra parte, ni el niño ni el adulto podrían distinguir del objeto mismo la adumbración perceptiva por la cual tienen acceso al objeto; en realidad, los identificará, por lo menos hasta que cambie la perspectiva que tiene sobre el objeto, acercándose desde otra posición posible. Un adulto, por lo menos, considerará una rama sobresaliendo encima de un muro, como algo que no se distingue del árbol, para utilizar el ejemplo de Piaget, en el sentido bastante diferente de que es una parte real de él. Según Peirce, un índice es un signo, cuyas partes están conectadas, independientemente de la función del signo, por contigüidad o por el tipo de relación que existe entre una parte y la totalidad correspondiente (que en otros textos hemos llamado factoralidad). Pero obviamente la contigüidad y la factoralidad están presentes por todos lados en el mundo perceptivo sin, por lo tanto, formar signos: diremos, en ese caso, que son meras indexicalidades. La percepción está atiborrada de indexicalidad (Véase Sonesson, 1992b).

Así, el mundo de la percepción tiene significación, aunque no conste de signos. Es "el mundo de la vida" que Greimas llama "el mundo natural" (natural para nosotros del mismo modo que nuestra lengua materna) y que Gibson, en la psicología de la percepción del mundo, da el nombre de "la física ecológica" (es la "física" cuyas leyes anula la magia). Tanto Greimas como Gibson leyeron a Husserl e incluso Gibson confirmó la tesis de Husserl en la que considera al mundo de la vida como la capa fundamental para nuestra experiencia de la significación, una condición para la percepción misma.

Si el mundo de la vida es el mundo que damos por supuesto, esto implica que establece las normas más fundamentales, casi inamovibles, las más difíciles de romper. Forma las estructuras de expectativas de base para todos los seres humanos (Véase Sonesson, 1992a, 3.1, 1996a, b; 2000). Es la realidad donde "siempre se puede seguir adelante" Es una de las cosas que lo diferencia del signo. 


\subsection{La televisión como cadena de espejos}

Eco (1984:216f) ha negado en varias ocasiones que el espejo sea un signo: en vez de estar en lugar de algo está frente a algo: la imagen del espejo no está presente en ausencia de su referente, es producida causalmente por su objeto y no es independiente del medio o del canal por el cual es transportada. En realidad, en sus trabajos más recientes, Eco (1998:22ff; 1999:371ff) amplía esta descripción a algunos fenómenos (entre ellos curiosamente la televisión) que la mayoría de la gente consideraría naturalmente como imágenes. Con referencia a nuestro concepto más exacto de signo, no veo ninguna razón para negar el carácter de signo al espejo: algo que es comparativamente más directo y menos temático, la imagen del espejo, representa a algo que es menos directo y más temático, el objeto delante del espejo; y la persona o la cosa delante del espejo se diferencian claramente de la imagen en el espejo. Por supuesto, los animales y los niños pequeños pueden tener dificultad para hacer esta diferenciación, pero esto es exactamente lo qué sucede en el caso de los signos, como Piaget ya lo ha indicado. La clase de diferenciación que los animales y los niños no experimentan es, al parecer, no la que implica una discontinuidad en el tiempo y/o el espacio (no piensan que la imagen del espejo forma parte de ellos mismos) sino la que se apoya en la naturaleza diversa de los dos correlativos (el gato confunde la imagen de un gato con otro gato).

Nada de lo que hemos dicho hasta ahora significa que el espejo sea idéntico en su funcionamiento a la imagen. Contrariamente a la imagen, el espejo realmente nos permite ver cosas nuevas en su superficie, cuando este último (o lo que está delante de él) se mueve, y ninguna de estas variantes son más "verdaderas" que las otras. No hay realmente nada que corresponda a la expresión, porque no hay contornos, o cualquier cosa que se pueda observar así, independientemente de la proyección de la profundidad a la cual dan lugar. Por otra parte, el espejo, contrariamente a la imagen, refleja todo tipo de objetos con la misma facilidad: la jerarquía de las cosas del mundo de la vida se puede aplicar al espejo también, pero esto no cambia su manera de representar estas cosas. El espejo tampoco

$\overline{\text { Significação } 20 \cdot 124}$ 
puede escoger representar intencionalmente el mundo a diversos niveles, como lo hace la imagen (excepto quizás en el caso de espejos distorsionantes).

Eco termina, a fin de cuentas, por postular una semejanza entre los espejos y las imágenes, empezando por la televisión. En esta parte de su argumentación, Eco (1998:22ff; 1999:371ff) comienza por decir que la televisión no se parece para nada a las imágenes, sino es como una cadena de espejos que se reflejan entre sí, con la excepción de que, en vez de las reflexiones de los espejos, hay una señal electrónica. En este sentido, la televisión no involucra a signos, sino es solamente un canal, exactamente como el espejo, o, más en general, como una prótesis, que no magnifica, como el telescopio, pero que da acceso a lugares donde no estamos presentes. Según el análisis de Eco, no hay ningún plano de expresión separado del contenido, al igual que en el caso del espejo, Exactamente como un telescopio o un espejo, la imagen de la televisión es experimentada como una vista directa de la realidad, y por consiguiente, se cree que se puede confiar en su verdad.

Sin embargo, hay limitaciones. La televisión, debido a su baja definición, es un espejo muy turbio. Y la analogía con la cadena de espejos vale solamente mientras la cámara fotográfica esté fija y enseñe todo lo que sucede en un lugar particular, en el momento mismo en que ocurre, porque tan pronto como esta condición no se realice totalmente, la televisión queda reducida a la película y al teatro. Además, la imagen de la televisión es más pequeña que los objetos reales reproducidos, y no es posible mirar oblicuamente a los lados de la imagen para descubrir nuevos objetos, como podemos hacer en un espejo. Por lo tanto, Eco concluye, la imagen de la televisión es sólo para-especular. No obstante, estas limitaciones pueden ser superadas: la imagen se puede hacer más grande, y la definición más alta: el caso de la camera de investigación intestinal. Cuando la camera de investigación intestinal se mueve dentro del cuerpo, podemos también ver oblicuamente, como en un espejo.

Esta teoría nos resulta absolutamente extraordinaria. Para comenzar, Eco está hablando de un caso idealizado a tal punto que casi puede existir. Incluso, como él mismo describe la imagen de la 
televisión, todo el tiempo está a punto de volverse en imagen de película por su misma turbiedad y el riesgo de un mise-en-scène. En realidad, una parte muy pequeña de lo qué se ve en la televisión se transmite hoy en día en directo. Totalmente aparte del hecho de que las técnicas modernas de computación permitan manipular las imágenes al mismo tiempo que son transmitidas directamente, la señal de la televisión, como tal, es diferente a la realidad que reproduce, por las mismas razones que esto se puede decir de la fotografía (Véase Sonesson, 1989b; 1999a, 2001): todo; las condiciones de la luz, la naturaleza la cámara fotográfica, el objetivo y las otras partes del equipo, la señal de la transmisión, etc., introducen modificaciones entre el referente y su imagen, comparables en todo a las que existen en otras imágenes; en realidad, como ya lo hemos visto, en oposición a Eco, esto también se aplica, de cierto modo, al espejo (Véase Sonesson a aparecer).

En cuanto a las modificaciones de las imágenes de televisión mencionadas por Eco, una definición más alta las harían más similares a las imágenes ordinarias, y un tamaño más grande no contribuye de ninguna manera a hacerlas diferentes de otras imágenes. Si no me equivoco, la cámara de investigación intestinal no nos permite de ninguna manera mirar oblicuamente a los lados de la superficie de la imagen, como el espejo; da lugar simplemente a nuevas imágenes, cuando se mueve dentro del cuerpo, como cualquier otra cámara fotográfica, sea una cámara de televisión o no. En realidad, el holograma, que al parecer Eco todavía cuenta como imagen, hace posible, en un grado limitado, cambiar de perspectiva dentro de la imagen, y también lo hacen, de una manera más impresionante, los dispositivos de computación que se suelen describir como una "realidad virtual"

La gente no cree que la televisión sea una mirilla directa sobre la realidad, como podría pensarse de los espejos o de los telescopios: si se toman en serio lo que ven en la televisión, es porque ésta tiene cierta autoridad, exactamente como la radio, o ciertos periódicos que inspiran confianza. En la medida que Eco tiene razón en sus afirmaciones, se trata simplemente de un hecho de sociosemiótica. 
No obstante, Eco (1998:24; 1999:375) da un paso más: se imagina que la película, la fotografía, la pintura hiperrealista son imágenes "congeladas" del espejo. La diferencia es que ahora la expresión está separada del contenido y así puede sobrevivir a la desaparición del último. Queda poco de la teoría convencionalista de las imágenes que, en otros pasajes, Eco está dispuesto a sostener, a pesar de hacer ciertas modificaciones. Así, regresamos al punto donde comenzamos, antes de la primera crítica a Eco, en el "mensaje sin código" de Barthes. Y de nuevo, la iconicidad aparece como un completo misterio.

\subsection{Más allá de la virtualidad: la invención de Bioy Casares}

En su libro "La invención de Morel", Adolfo Bioy Casares (1940), cuenta la historia del multimedium perfecto, mucho antes de que este término fuera inventado. Un hombre llega a una isla desierta y descubre poco a poco que la isla no está tan desierta como había creído; aparecen personas en palacios y en paisajes aledaños a donde está él. Este hombre se esconde y observa, especialmente a una mujer de la cual pronto cae enamorado; con gran angustia decide salir de su escondite y declararle su amor - no sin antes haber meditado sobre todas sus posibles reacciones. Sin embargo, ella no reacciona a su acercamiento, es como si él no existiera y en efecto, no existe para ella.

Todo lo que ha observado, resulta ser una especie de grabación que sale de algunos aparatos en el sótano del palacio y que se repite una y otra vez. Se trata de una proyección tridimensional que contiene todas las modalidades sensoriales (por lo que se puede deducir).

Esta es la invención de Morel. Es tan parecida a la realidad, al mundo que damos por obvio, que nada en su forma dice que sólo es una imagen, sólo un signo. Si algo la denuncia como signo, es el hecho que se repite continuamente: consta de réplicas de un mismo tipo. Sin embargo, carece de lo que los multimedia perfectos permiten: 
interactividad (el hombre no puede relacionarse con la mujer), también en el sentido elemental de respuesta social (contrariamente a lo que nuestro héroe cree, la mujer no tiene ninguna posibilidad de ignorarlo significativamente). En consecuencia, es en el plano social que esta "realidad virtual" finalmente no cumple con el criterio de Husserl de la posibilidad de siempre seguir adelante.

Así, el yo del libro decide entrar en el relato y dejarse grabar, aunque esto signifique su muerte en el mundo real; es como si se pudiera entrar en la realidad virtual para quedarse allí. Sin embargo, aquí es válido justamente lo que señalaba Husserl de las imágenes corrientes; si se confunde la imagen con la realidad, como se puede hacer si se observa la primera con un ojo inmóvil a través de un hoyo, no se la ve como una imagen, es decir, como signo. En la medida que la realidad virtual se experimenta como real deja de ser virtual.

Cuando Bioy Casares escribió su novela, la televisión era todavía un medio futurista. Por ese concibe el mundo virtual como una especie de cinta grabada reproduciendo todos los sentidos. Tal vez como Eco, lo veía como un espejo. Para nosotros, tiene algo de multimedium, porque contiene información accesible a todos los sentidos de los seres humanos (aunque, si no nos equivocamos, el yo de la historia nunca trata de tocar a los personajes), y algo de la realidad virtual, porque da una ilusión de realidad, sin, no obstante, requerir el aislamiento de la realidad realmente real.

Más aún hace pensar en una mezcla de los dos últimas variantes del viejo arquetipo del robot: algo intermedio entre los autómatas reales que son capaces de evitar obstáculos o de levantar bloques, y los personajes artificiales llamados "avatares" que viven nada más dentro de los ordenadores. Para la decepción de nuestro héroe, sus personajes no son interactivos como los primeros, y parecen tener una existencia más concretamente material que los últimos. Pero tienen en común con las dos los tipos de autómatas reales el hecho de vivir en el límite entre el signo y la realidad.

En el cuento de Bioy Casares, el héroe entra en el domino del signo. En la fantasía de los constructores del mundo virtual, son los signos que cruzan la frontera en dirección a la realidad. Pero mientras el pasaje siempre es posible, y la frontera puede ser 
desplazada un poco hacia el frente o hacia atrás, hay toda la razón para pensar que la frontera siempre seguirá existiendo. Cada realidad tiene su signo, como cada signo tiene su realidad.

\section{Bibliografia}

BAKHTIN, M.N. 1990. Art and Answerability. Austin: University of Texas.

BARTHES, R. 1961. "Le message photographique" Communications $1, .128-130$.

1964. "Rhétorique de l'image" Communications 4. 40-51.

. 1980. La chambre claire. Paris: Seuil \& Galllimard.

BENJAMIN, W. 1974. "Das Kunstwerk im Zeitalter seiner technischen Reproduzierbarkeit" Gesammelte Schriften I:2. Frankfurt: M. Suhrkamp, 471-508.

BIOY CASARES, A. 1940. La invención de Morel. Buenos Aires: Emecé Editores.

DUBOIS, Ph. 1983. L'acte photographique. Paris \& Bruxelles: Nathan/ Labor

ECO, U. 1968. La struttura assente. Milan: Bompiani. Press

1976. A theory of semiotics. Bloomington: Indiana University

1984. Semiotics and the philosophy of language. Bloomington: Indiana University Press.

. 1998. "Réflexions à propos du débat sur l'iconisme (1968-1998)" VISIO, 3, 1, 9-32. Co.

1999. Kant and the platypus. New York: Harcourt Brance \&

ENNION, E.A. R.; TINBERGEN, N. 1967. Tracks. Oxford: The Clarendon Press.

GIBSON, J. 1978. "The ecological approach to visual perception in pictures" Leonardo, 11:3, 227-235.

1980. "A prefatory essay on the perception of surfaces versus the perception of markings on a surface" The perception of 
pictures, Volume I: Alberti's window. HAGEN, M., ed., xi-xvii. New York: Academic Press.

GRICE, P. 1989. Studies in the way of words. Cambridge: Harvard University Press.

GOODMAN, N. 1968. Languages of art. Oxford University Press, London.

GREENLEE, D. 1973. Peirce's concept of sign. The Hague \& Paris: Mouton 1973.

GUBERN, R. 1974. Mensajes icónicos en la cultura de masas. Barcelona: Ediciones Península. - 1987a. El simio informatizado. Madrid: Fundesco.

- 1987b. La mirada opulenta. Exploración de la iconosfera contemporánea. Barcelona: Gustavo Gili.

INNES, H. 1950. Empire and communication. 2.ed. Toronto: University of Toronto Press, 1972.

IVINS, W. M. 1953. Prints and visual communcation. Cambridge, Mass.: Harvard University Press.

JAKOBSON, R. 1975. Coup d'œil sur le développment de la sémiotique. Bloomington: Indiana University Press.

LEVINSON, S. 1983. Pragmatics. Cambridge: Cambridge University Press.

LOTMAN, J. M; USPENSKIJ, B. A.; IVANOV, V. V.; TOPOROV, V. N.; PJATIGORSKIJ, A. M. 1975. Thesis on the semiotic study of culture. Lisse: The Peter de Ridder Press.

LURÇAT, L. 1974. Etudes de l'acte graphique. Paris \& La Haye: Mouton.

MALDONADO, T. 1974. Vanguardia e razionalità. Turin: Einaudi Ed.

MASUDA, Y. 1980. Information society as post-industrial society. Washington, D.C.: World future society.

METZ, C. 1990. "Photograph and fetisch" The criticial image. Essays on contemporary photography. SQIOERS. CAROL, ed. 155-164. Seattle: Bay Press.

MOLES, A. 1971. Art et ordinateur. Tournai: Casterman S.A. 1981. L'image communication fonctionelle. Bruxelles: Casterman.

$\overline{\text { Significação } 20 \cdot 130}$ 
PIAGET, J. 1970. Epistémologie des sciences de l'homme. Paris: Gallimard.

POSNER, R. 1989. "What is culture? Toward a semiotic explication of anthropological concepts" In: $\mathrm{KOCH}, \mathrm{W}$. (ed.). The Nature of Culture, 240-295. Bochum: Brochmeyer.

RAMIREZ, J. A. 1981. Medios de masas e historia del arte. Madrid: Ediciones Cátedra.

SCHAEFFER, J-M. 1987. L'image précaire Paris: Seuil.

SAVAN, D. 1976. An Introduction ot C.S. Peirce's Semiotics. Toronto: Toronto Semiotic Circle.

SONESSON, G. 1987. Bildbetydelser $i$ informationssamhället. Lund: Semiotics Project.

1989a. Pictorial concepts. Inquiries into the semiotic heritage and its relevance for the analysis of the visual world. Lund: Aris/Lund University Press.

. 1989b. Semiotics of photography. On tracing the index. Lund: Semiotics Project.

1992a. Bildbetydelser. Inledning till bildsemiotiken som vetenskap. Studentlitteratur, Lund.

1992b. "The semiotic function and the genesis of pictorial meaning" Center/Periphery in representations and institutions. Tarasti, Eero (ed.), 211-156. Imatra: Acta Semiotica Fennica.

. 1995a. "On pictorality. The impact of the perceptual model in the development of visual semiotics" In: SEBEOK, Th.; UMIKER-SEBEOK, J. (eds.).The semiotic web 1992/93: Advances in visual semiotics, pp. 67-108. Berlin \& New York: Mouton de Gruyter.

1995b. "Livsvärlden mediering. Kommunikation i en kultursemiotisk ram" In: HOLMBERG, Claes-Göran; SVENSSON, Jan (eds.). Medietexter och mediatolkningar, pp. 33-78. Nora: Nya Doxa.

. 1995c. "Indexicality as perceptual mediation". In: PANKOW. C. (ed.). Indexicality, pp. 127-143. Gothenburg: SSKKII

1996a. "An essay concerning images. From rhetoric to semiotics by way of ecological physics" Semiotica 109-1/2, 41140.

1996b. "De la retórica de la percepción a la retórica de la cultura" Heterogénesis 15, 1-12. 
. 1997a. "Semiótica cultural de la sociedad de la imagen" In: Heterogénesis, 20, 16-37

.1997b. "Approches to the lifeworld core of pictorial rhetoric" VISIO 1:3, 49-76.

1998a. "The concept of text in cultural semiotics". In: TOROP, P.; LOTMAN, M.; KULL, K. (eds.). Semiotiké. Trudy po znakovym sistemam/Sign system studies 26, pp. 83-114. Tartu: Tartu University Press.

$3,1,33-54$

1998b. "That there are many kinds of pictorial signs" VISIO,

1998c. «Icon », « Iconicity », «Index », « Indexicality », «Metonymy », etc. In : BOUISSAC, P. (ed.). Encyclopaedia of Semiotics. New York \& London: Oxford University Press.

. 1999a. "Post-photography and beyond. From mechanical reproduction to digital production" VISIO, 4, 1, 11-36.

. 1999b) "The life of signs in society - and out of it". In: TOROP, P.; LOTMAN, M.; KULL, K. (eds.). Semiotiké. Trudy po znakovym sistemam/Sign system studies 27. pp. 88-127 Tartu: Tartu University Press.

. 2000. "Iconicity in the ecology of semiosis" In: DENG JOHANSSON, T.; SKOV, M.; BROGAARD, B. (eds.). Iconicity A Fundamental Problem in Semiotics, pp. 59-80. Aarhus: NSU Press. 4, 27-53.

2001. "The pencils of nature and culture" Semiotica 136-1/ .2002. "The varieties of interpretation, A view from semiotics" Galáxia 4, 67-99.

a aparecer. "Iconicity strikes back: the third generation - or why Eco still is wrong". In: Actes du 6ème Congrès de l'Association internationale de sémiotique visuelle, Québec, Québec, octobre 2001.

VANLIER, H. 1983. Philosophie de la photographie. Laplume, Les cahiers de la photographie. 